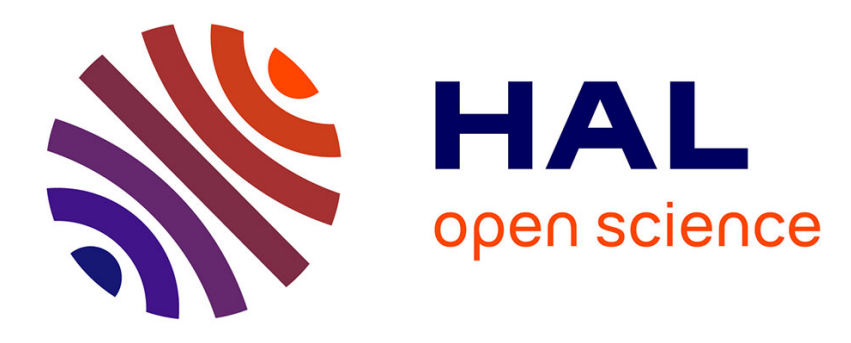

\title{
Effects of Additives and Templates on Calcium Carbonate Mineralization in vitro
}

Dongni Ren, Qingling Feng, Xavier Bourrat

\section{To cite this version:}

Dongni Ren, Qingling Feng, Xavier Bourrat. Effects of Additives and Templates on Calcium Carbonate Mineralization in vitro. Micron, 2011, 42 (3), pp.228-245. 10.1016/j.micron.2010.09.005 . insu00520593

\section{HAL Id: insu-00520593 https://hal-insu.archives-ouvertes.fr/insu-00520593}

Submitted on 23 Sep 2010

HAL is a multi-disciplinary open access archive for the deposit and dissemination of scientific research documents, whether they are published or not. The documents may come from teaching and research institutions in France or abroad, or from public or private research centers.
L'archive ouverte pluridisciplinaire HAL, est destinée au dépôt et à la diffusion de documents scientifiques de niveau recherche, publiés ou non, émanant des établissements d'enseignement et de recherche français ou étrangers, des laboratoires publics ou privés. 


\section{Effects of Additives and Templates on Calcium Carbonate}

\section{Mineralization in vitro}

Dongni Ren ${ }^{\mathrm{a}}$, Qingling Feng ${ }^{\mathrm{a}^{*}}$ and Xavier Bourrat ${ }^{\mathrm{b}}$

${ }^{a}$ Laboratory of Advanced Materials, Department of Materials Science and Engineering,

Tsinghua University, Tsinghua University, Beijing 100084, People’s Republic of

China

Tel: 86-10-62782770; Fax: 86-10-62771160

E-mail: biomater@mail.tsinghua.edu.cn

${ }^{\mathrm{b}}$ Universite d'Orleans et Tours, CNRS-ISTO, Institut des Sciences de la Terre

d'Orléans , 1A, rue de la Férollerie, 45071 ORLEANS CEDEX 2, France

E-mail: Xavier.Bourrat@univ-orleans.fr 


\section{Abstract}

The review focuses on the effects of several important additives and templates controlling the calcium carbonate crystals formation and the complexity of the crystal morphologies in vitro. Additives include soluble matrices extracted from shells and pearls, amino-acids, magnesium ions and collagen among others. Templates include modified single crystal silicon, natural biominerals among others. Mechanisms proposed to explain the phenomena are not systematic, further studies are necessary to explain how organic matrices mediate calcium carbonate mineralization.

Keywords: additive; template; in vitro mineralization; calcium carbonate crystal 


\section{Introduction}

Biomineralization involves the selective extraction and uptake of elements from the local environment and their incorporation into functional structures under strict biological control (Mann, 2001). The formation of hard bioinorganic materials such as bones and shells is univocally recorded in the fossil record, the biological processes were involved in inorganic mineralization stretching as far back as 3500 million years. Moreover, the fossils contain a record not only of the distant biology but also of the local climate and chemical conditions of the marine environment now long gone.

Compared with manual composite materials, natural biomineralized materials have specific hierarchical structure and assembling method. By revealing its regulation mechanism, it could provide ideas for similar issues as material science, and also new models of biomimetic materials. Modern study on mineralization begins with Lowenstam's (Lowenstam, 1981) theory as "minerals formed by organisms", emphasized the important character of macromolecules in the mineralization process, he also pointed out the differences between biological controlled mineralization and organic induced mineralization. Comparing with inorganic minerals, which are hard, stiff but brittle, organic materials are relatively soft, compliant but tough (Stempfle et al., 2007), so there is much to be gained in the mechanical design of life if the 'organic toughness' is married with the 'inorganic strength'. Biomineralization offers an organism more than just structural support and mechanical strength. As nature's master builder, it is involved in a wide variety of important biological functions such as: 
protection, motion, cutting and grinding, buoyancy, storage, optical detection, magnetic and gravity sensing. In summary, the big picture of biomineralization contains many different subjects and perspectives, ranging from the global aspects of the earth science to the local niches of biology, the selection pressure on material design, the tissue anatomy and the microscopic world of cells (Mann, 2001).

Many leading scientists over the world like Williams, Mann and Weiner et al. have devoted their researches to the understanding of the biomineralization process as organic-inorganic interfacial recognition, molecular recognition and molecular geometric matching, et al. The research theories developed from microscale to nanoscale, from structure conformation to biomimic preparation, from theory analysis to biomimetic synthesis, from cell mediation to gene mediation (Davis, 2004; Ameye et al., 2001; Hunter, 1996; Choi and Kim, 2000; Ogasawara et al., 2000; Sarikaya et al., 1999; Mann and Ozin, 1996).

Carbon-based minerals are the most important inorganic phase materials of biomineralization systems. Calcium carbonate is one of the most important biominerals that has been a research focus for decades. There are three crystal forms of anhydrous calcium carbonate: calcite, aragonite and vaterite, and their crystal systems are rhombohedral, orthorhombic and hexagonal, respectively (de Leeuw and Parker, 1998). In aqueous environment at $25{ }^{\circ} \mathrm{C}$, they have decreasing stabilities and increasing solubility limits. Their solubility constant $\left(K_{s p}\right)$ values are $10^{-8.48}, 10^{-8.34}$ and $10^{-7.91}$ (Plummer and Busenberg, 1982), respectively. Geological minerals of calcium carbonate are almost all calcites with a few aragonites, since the Gibbs free energy of 
calcite is the lowest of the three. In biominerals, calcite and aragonite are the most common forms of calcium carbonate crystals, which exist mainly in mollusk shells and bird eggs (de Leeuw and Parker, 1998). Vaterite is metastable, the most unstable crystal form of calcium carbonate, and would automatically transform into calcite or aragonite in aqueous solution. But in natural systems like carp asteriscus (Li and Feng, 2007) (Figure 1) and fresh water lackluster pearls (Hang, 1994) (Figure 2), it turned out that vaterite could be stable. Based on their unique characteristics, vaterite and amorphous calcium carbonate (ACC) have become research hot spots in recent years. In order to understand how protein matrices mediate calcite, aragonite and vaterite in living organisms, and how complicated microstructures are formed, many experiments were processed in vitro to simulate biomineralization.

\section{Effects of Additives on Calcium Carbonate Mineralization in vitro}

\subsection{Soluble matrices (SM) in the solution as additives}

In most biomaterials, inorganic component is the dominant phase in weight or volume.

Protein matrices, polysaccharides and others compose the inorganic phase. Studies for years have proved that proteins are the most important influence factors in the formation of calcium carbonate crystals. One of the most commonly used method to study the effect of proteins on mineralization of calcium carbonate crystals is to extract, separate them from natural biominerals and add into simulation systems, to study their functions under different conditions in vitro.

In the biomineralization process, organic matrix mediating inorganic crystal nucleation, 
growth, crystal polymorph and orientation is very complex and extremely important. The organic matrix distribution could be in various forms: continuous lamellar distributed in intra platelet, or inter-platelet encapsulating inorganic crystals, or discontinuous distributed in the interior of crystals, or even form an independent shell. The simplest mode of organic matrices connection is that, the matrix skeleton is mainly composed of cross-linking hydrophobic structure framing, hydrophilic matrix is fixed on its surface, and providing an active nucleation surface for external solution.

The insoluble organic matrix distribute in intra- or inter-platelet, is composed of collagen, $\beta$-keratin, chitin et al., provides soluble matrix joint substrate, and controls crystal growth into it, decides the crystal size and orientation. Soluble matrix mainly composed of acidic polymers, distribute on the surface of insoluble matrix, directly contact the crystal or distribute in the interior of the crystal. Soluble matrix along with the mesh of insoluble matrix could bind calcium and provide nucleation sites. On the contrary, soluble matrix exist in solution could inhibit nucleation. Soluble matrix could decide crystal polymorphs, and mineral growth, and act importantly in cellular activities, such as ion transportation, enzyme regulation and hormone stimulation et al. In previous studies, organic matrices were extracted by their solubility in sodium ethylenediaminetetraacetic acid (EDTA), and were classified as insoluble matrix (IM) proteins and soluble matrix (SM) proteins. IM and SM were found to play different roles in controlling the polymorph and morphology of calcium carbonate. IM proteins are normally structure molecules, and provide SM joint sites as substrates. In the mineralization process, IM could control crystal growth, which influences the size and 
orientation of the crystals. SM proteins are mainly composed of acidic macromolecules, distributing on the surface of IM, could either directly touch with crystals, or distribute in crystals. The SM matching the holes of IM could combine calcium, and provide nucleation sites. By contrast, when SM is in solution, it can inhibit the crystal formation. SM proteins mainly decide the crystal polymorphs in organism, may possibly control crystal growth, and also act importantly in biominerals concerning with cell activities, such as ion transportation, enzyme regulation and hormone stimulations et al. (Qiao, 2008). In studies of Feng (Feng et al., 2000), Belcher (Belcher et al., 1996), Falini (Falini, 1996), Samata (Samata et al., 1999) and Kono (Kono et al., 2000), it showed that IM proteins mainly act as structure frames, providing nucleation sites for calcium carbonate crystals while SM proteins control the polymorphs.

Many in vitro mineralization experiments have proved that, SM extracted from calcite biominerals could induce calcite growth, and SM extracted from aragonite biominerals could induce aragonite growth. For example, the matrix proteins extracted from nacreous layer (aragonite crystals) in mollusk shell Mytilus edulis induced aragonite formation, while those extracted from prismatic layer (calcite crystals) induced calcite formation (Feng et al., 2000). SM extracted by Belcher et al. (Belcher et al., 1996) from shells of Haliotis refescens abalone could well induce aragonite, so it was believed that SM alone could control the polymorph and morphology of calcium carbonate crystals, IM was not necessary. Feng et al. (Feng et al., 2000) proved that IM from nacre of shell Mytilus edulis could influence the size and density of the crystals 
(Figure 3). While Falini et al. (Falini, 1996) pointed out that besides SM, IM could also control calcium carbonate crystal polymorphs. They chose SM from biominerals with different calcium carbonate crystals, while IM from $\beta$-chitin and silk-fibroins of other animals, adding them into the system with different combinations. The results showed that SM and IM together could induce the same $\mathrm{CaCO}_{3}$ crystal polymorph with the biominerals of which SM were extracted, but $\beta$-chitin and SM together without silk-fibroin could only induce calcite crystals, no matter whether the SMs were extracted from nacreous layer (aragonite crystals) or prismatic layer (calcite crystals). On the other hand, IM alone did not have any influence on the polymorph. The results showed that SM is one of the most important factors for crystal control, but not the only one. From the above results we can see that different results with different conditions could explain a same natural phenomenon: we are still not holding all the information on proteins mediated biomineralization.

With the development and fulfillment of theories and technologies, new fields of protein mediated biomineralization emerged. New protein matrices extraction method was developed by Lopez group of National Museum of Natural Science in Paris, France (Pereira-Mouries et al., 2002). Acetic acid and Milli-Q water, replacing EDTA were used in experiments in order to avoid the potential damage of protein structures. In this way, water-soluble matrix (WSM), acid-soluble matrix (ASM) and acid-insoluble matrix (AIM) can be extracted from pearls. Pearls produced by the fresh water mussel Hyriopsis Cumingii crystallize sometimes in the form of vaterite instead of aragonite (vaterite appears in yellow when observed by cathodoluminescence). 
Using this new extraction protocol, the so-called water soluble organic matrix, WSM, was extracted and used as additive in controlled calcium carbonate growth experiments. Vaterite crystals were grown for the greater part when WSM from vaterite pearls was added in the solution. The formation of vaterite appears to be clearly connected to the water-soluble matrices. Such kind of extraction method could also define different effects of protein matrices in a more detail way. Using biochemical methods like reverse-phase high-performance liquid chromatography and SDS-PAGE, scientists have succeeded in obtaining purified proteins, such as nacrein (Miyamoto et al., 1996), lustrin A (Shen et al., 1997), MSI60 (Sudo et al., 1997), N16 (Samata et al., 1999), pearlin (Miyashita et al., 2000), mucoperlin (Marin et al., 2000), N14 (Kono et al., 2000), N66 (Kono et al., 2000), perlucin (Weiss et al., 2000), perlustrin (Weiss et al., 2000), p20 (Bedouet et al., 2001), MSI7 (Zhang et al., 2003), AP7 (Michenfelder et al., 2003), AP24 (Michenfelder et al., 2003), p10 (Zhang et al., 2006), AP8 (Fu et al., 2005) and a 48kDa protein from Hyriopsis cumingii (Natoli et al., 2010). Some of their effects on mineralization under in vitro conditions were studied. Almost all these protein matrices were extracted by EDTA or weak acids (acetic acid normally) dissolving the calcium carbonate crystals, and were classified by their dissolubility. But, the formation of natural biominerals is a very complicated process, in which a series of proteins are involved. Despite many researches about how proteins work in the mineralization process in organisms, a lot of issues are still not figured out clearly, mainly because a tiny content might be extremely important in such processes. 


\subsection{Amino acids in the solution as additives}

Amino acid analyses of SM indicate that the three most important amino acids are glycine, aspartic acid, and glutamic acid (Levi et al., 1998).

Wentao Hou and Qingling Feng (Hou and Feng, 2006) studied the function of glycine in the mineralization system. They selected two methods to precipitate $\mathrm{CaCO}_{3}$ particles: titration method and diffusion method. In titration method, under stirring condition, with short depositing time, both calcite and vaterite particles were formed, and the proportion of vaterite increased with the increase of glycine concentration. The shape of calcite and vaterite are normally rhombic and spherical respectively (Figure 4). By extending the deposition time, all calcium carbonate crystals turned to vaterite particles with spherical and spindly morphologies, regardless the concentration of glycine. The results showed that stirring condition itself was sufficient to induce formation of spindly vaterite when the dripping velocity was slow enough. The possible reason is that stirring changed the nucleation activation energy $\left(\Delta \mathrm{G}_{\mathrm{n}}\right)$ of calcite and vaterite in the aqueous system so that their nucleation priorities were inverted (Mann et al., 1993). It was also found that, rapid titration produced local instantaneous high supersaturation to overcome the nucleation energy barrier of both calcite and vaterite. On the other hand, slow titration provided a longer time for nucleation and limited the supersaturation value to induce vaterite. In the diffusion method with glycine as additive, without stirring, depositions were almost all spherical vaterite particles without any spindly ones. It was thus deduced that the spindly shape occurring in the titration experiments was directly caused by stirring. It was also supposed that, glycine 
may change the activation energy of nucleation in aqueous solutions, similar to the function of stirring. In the presence of glycine, calcite $\Delta \mathrm{G}_{\mathrm{n}}\left(\Delta \mathrm{G}_{\mathrm{n}}=\Delta \mathrm{G}_{\text {surface }}+\Delta \mathrm{G}_{\text {bulk }}\right)$ became relatively higher than that of vaterite, which could provoke the priority deposit of vaterite. The possible reason is that, carboxyl group of glycine may affect hydrated surface energies in solution (de Leeuw and Parker, 1997) by interacting with calcium ions, like the behavior of surfactants (Donners et al., 2002). The solution height may also be an important factor since the determinant factor in the Gibbs formula is no more surface energy but bulk lattice energy, which was in accordance with the result of all aragonite formation. When the height of the solution was lowered, the bulk lattice energy of aragonite became the lowest.

Glutamic acid and aspartic acid are both acidic amino acids that exist in biominerals: their influences on calcium carbonate mineralization have been studied intensively. It is illustrated that their functions may lie in the negative electricity of $R$-radical, which would absorb dissociate $\mathrm{Ca}^{2+}$ ions or $\mathrm{Ca}^{2+}$ ions on crystal surfaces, so as to change the crystallization process of calcium carbonate. It is found that both glutamic acid and aspartic acid have the ability to induce vaterite growth in solution. Hua Tong et al. (Tong et al., 2004) succeeded in mediating porous vaterite crystals, considering it was due to the absorption between aspartic acid and the surface of calcium carbonate crystals, and inhibited formation of calcite. Manoli et al. (Manoli and Dalas, 2001) found that glutamic acid could stabilize vaterite crystals.

In mineralization process, not only crystal polymorph, but also morphology is influenced by amino acids. In very low solution height system (Hou and Feng, 2006), 
which is more likely to happen in biominerals, only calcite crystals were formed, vaterite and aragonite were missing. Calcite morphology changed with different amino acids in the solution. Aggregates were found in both glycine and aspartic acid systems, and the difference between glycine and aspartic acid is that aspartic acid is an acidic amino acid that has two -COO- groups in one molecule. This is a possible reason for which aspartic acid has the ability of agglutinating two or more nuclei, glycine does not seem to have this ability.

\subsection{Magnesium ions and collagen in solution as additives}

Since sea water contains $0.13 \mathrm{wt} \%$ of $\mathrm{Mg}$, people have been interested in how $\mathrm{Mg}^{2+}$ influences calcium carbonate mineralization in marine animals. It is known that $\mathrm{Mg}^{2+}$ can replace $\mathrm{Ca}^{2+}$ in calcite, but cannot inter crystal lattice in aragonite. So, in conditions of high $\mathrm{Mg} / \mathrm{Ca}$ ratio, calcite nucleation would be inhibited and aragonite nucleation would be favored. This is the way Mg mediates the two calcium carbonate polymorphs (Mann, 2001). People also discovered that $\mathrm{Mg}^{2+}$ could promote amorphous calcium carbonate (ACC) formation. Raz et al. (Raz et al., 2003) studied ACC in the spicule of Juvenile sponge, they found that only calcite was formed without $\mathrm{Mg}^{2+}$ in the solution, and the spicule protein could not mediate ACC formation alone; $\mathrm{Mg}^{2+}$ is extremely important for ACC stabilization. They also pointed that calcite was transformed from ACC in high $\mathrm{Mg}^{2+}$ concentration (Figure 5). Meldrum et al. (Loste et al., 2003) also found that $\mathrm{Mg}^{2+}$ combination could defer ACC transformation, for the most part. Such effect was seen to be intensified with the amount of $\mathrm{Mg}^{2+}$. 
In biomineralization processes, the formation of inorganic crystals is controlled by organic macromolecules such as proteins (Mann, 1996; Addadi and Weiner, 1985). Collagen is the most important water insoluble fibrin which represents the framework of extracellular matrix. The basic structure of collagen is tropocollagen, and its primary structure has a repetitive sequence of $(\mathrm{Gly}-\mathrm{x}-\mathrm{y})_{\mathrm{n}}$, of which $\mathrm{x}$ usually represent Pro, and y of Hy-Pro or Hy-lys. Shen FH et al. (Shen et al., 2002) studied collagen mediated calcium carbonate grown in vitro, in order to reveal the principle of protein role in the process. The results of XRD and SEM of calcium carbonate crystal deposition showed that only calcite was formed: calcite growth is more and more inhibited as collagen concentration increasing (Figure 6). It means that collagen does not change the polymorph of calcium carbonates. With the increasing concentration of collagen, the morphology of calcite changed from perfect rhombohedral to well faceted rhombohedral crystals with little disfigurement, and then to overgrown calcite crystals with new planes. The thickness of new layers became thinner with the increasing of collagen, some of the calcite crystal planes would develop into a flower-like form, and they become spherulites as the concentration further increases $(>10 \mathrm{~g} / \mathrm{l})$. The authors provided an explanation, collagen would adsorb on the edges of $\{104\}$ planes of calcite, which are parallel to the c-axis, and inhibited its growth, and thus new planes appeared. The new planes started to appear at the edges of rhombohedral calcite crystals when collagen was present in the solution, since crystal growth starts at edges and corners, which provided good attachment sites, it led to the decrease of growth rate and new planes growth on such positions. New planes formed have better attraction for collagen, 
which would eventually alternate the morphologies. Collagen additive not only influenced morphology of the crystals, but also the quantity. Number of crystals mounted up, while size diminished with the increase of the protein concentration. The adsorption of protein from solution onto a solid plane is determined by the stability of its structure. One unique characteristic of collagen is its structure stability, and behaves as colloidal particles and only adsorbs onto ionic planes.

Jiao YF et al. (Jiao et al., 2006) studied the joint influence of $\mathrm{Mg}^{2+}$ and collagen. It was confirmed that $\mathrm{Mg}^{2+}$ could stabilize amorphous calcium carbonate and control calcite morphologies. They also found that $\mathrm{Mg}^{2+}$ could induce spherical aragonite and vaterite (small amount), and such action was amplified by collagen. But collagen alone had no significant influence on the polymorphs of calcium carbonate crystals, and almost all calcite crystals were formed, which showed that collagen had a promotional effect on magnesium ions in controlling the polymorph of $\mathrm{CaCO}_{3}$ crystals (Figure 7). They also provided an explanation, magnesium was likely to react with collagen to change the stereochemical structure of collagen molecules, and thus induced aragonite or vaterite. As summary, it emerges the general idea that polymorphs are controlled by their nucleation energies in the system. There are three ways to change nucleation priority: influence on $\Delta \mathrm{G}_{\text {surface }}$ like glycine, influence on $\Delta \mathrm{G}_{\text {bulk }}$ like $\mathrm{Mg}$ ions, and influence on the relationship between $\Delta \mathrm{G}_{\text {surface }}$ and $\Delta \mathrm{G}_{\text {bulk }}$ (influence on the nucleation type) like choosing low solution height.

\subsection{Non-biological macromolecules in solution as additives}

Another way consists in controlling the structure using macromolecules with designed 
fragments as additives in order to produce particular crystals with special morphologies.

Poly-aspartic acid was used by Gower et al. (Gower and Tirrell, 1998) as additive, it could induce calcite crystals with spiral holes on the surface (Figure 8), and hollow spiral vaterite crystals. Membrane depositions on glass substrates were obtained at higher poly-aspartic acid concentration. It was analyzed as crystal nucleus formed along the poly-aspartic acid surface. Falini et al. (Falini, 2000; Falini et al., 2000) carried out experiments with the gel of poly-aspartic acid and poly-glutamic acid, by changing the content of polymers in gel, calcite, aragonite and vaterite crystals with certain orientations were mediated, which proved that the micro-environment is very important in determining the crystal polymorphs. Kato et al. (Kato, 2000) used chitin as substrate and poly(acrylic acid), $\mathrm{Mg}^{2+}$ as additives, induced aragonite double-layered composite film (Figure 9). Hardikar et al. (Hardikar and Matijevic, 2001) studied the function of dextrans, and pointed out that, in the presence of urea, calcium carbonate particles were influenced significantly by the anionic dextran, which affected both the morphology and the crystal structure (Figure 10).

Double hydrophilic block copolymers (DHBCs) as additives are studied by many people on their effects on calcium carbonate mineralization. Guillemet et al. (Guillemet et al., 2006) using composite of poly(ethylene oxide) (PEO) and poly(acrylic acid) (PAA) blocks (PEO-b-PAA), successfully stabilized spherical ACC particles (Figure 11). Kulak AN et al. (Kulak et al., 2007) used poly(ethylene oxide)-b-poly(sodium 4-styrenesulfonate) diblock copolymer (PEO-b-PNaSS) with the control of the reaction 
conditions in effecting a morphological change in calcite particles, and a continuous

structural transition in the product particles from polycrystalline to mesocrystal, and to single crystal was observed with variation in the calcium concentration (Figure 12). They pointed out that, the various pathways to polycrystalline, mesocrystal, and single crystal particles, all form part of a unifying crystallization framework based on the aggregation of precursor subunits.

\section{Effects of templates on calcium carbonate mineralization in vitro}

The formation of biominerals is also controlled by organic template molecules resulting in materials with unique shapes and properties. Templates used in in vitro mineralization refer in particular to those substrates with particular sequence fragments that could mediate special mineral crystals. It is generally believed that the template molecules act as nucleators for the inorganic material and that the surface chemistry of the template induces oriented nucleation of the complementary crystal face. The presence of biomacromolecule turns the deposition process of $\mathrm{CaCO}_{3}$ from homogeneous nucleation to heterogeneous nucleation, and the reaction condition reaches the kinetic limitation requirements ( $\mathrm{Xu}$ et al., 2008). Polymer molecules adsorbed on the glass substrate can provide the conditions for heterogeneous nucleation of aragonite crystals, which is then under certain conditions energetically more favorable than homogeneous nucleation of calcite crystals in solution (Pokroy, 2005).

The history of using templates in in vitro mineralization experiments could date back 
to 1988, when Mann (Mann et al., 1988) chose Langmuir monomolecular membrane, taking advantage of its ordered arrangement of radicals to mediate calcium carbonate crystal growth.

\subsection{Self-assembled monolayers (SAMs) as template}

One of the most famous experiments using templates was carried out by Aizenberg (Aizenberg, 2000). She used micropatterned self-assembled monolayers (SAMs) which served as spatially constrained micro-environments for crystallization and synthesized patterned calcite films of which the nucleation, size and orientation of the crystals could be controlled. The method was also described as micro-contact printing. The special "ink" was used in the experiment, such as $\mathrm{HS}\left(\mathrm{CH}_{2}\right)_{\mathrm{n}} \mathrm{X}\left(\mathrm{X}=\mathrm{COOH}, \mathrm{SO}_{3} \mathrm{H}, \mathrm{OH}\right)$. After its micro-contact with the substrate, the terminal with sulfur atoms would attach to the substrate, so as to expose the X-radical. The terminal that was not in contact with the substrate was washed by $\mathrm{HS}\left(\mathrm{CH}_{2}\right)_{n} \mathrm{CH}_{3}$, which led to the exposure of $-\mathrm{CH}_{3}$. Put such templates bottom up in supersaturated solution of calcium carbonate, since the $\mathrm{X}$-radical would absorb $\mathrm{Ca}^{2+}$, and induce nucleation, calcium carbonate crystals with unique patterns were formed on the substrate with such templates. There was nothing at sites without templates. Some figures are shown below (Figure 13).

\subsection{Glass, single crystal silicon and modified single crystal silicon templates}

In in vitro mineralization experiments, glass substrate is often used because of its good characters like extensive resources, convenient usage, cheap price et al., but glass surface may induce aragonite crystals. (Hou and Feng, 2005) Single crystal silicon is 
another commonly used substrate. The single crystal silicon substrate should be treated by HF acid to remove surface oxide layer, then cleaned by acetone, absolute ethyl alcohol and deionized water to expose the (100) crystal plane. Li Zhuo (Li, 2008) tentatively studied radical influence on polymorph of calcium carbonate crystals by surface modification with $-\mathrm{OH},-\mathrm{NH}_{2}$ and $-\mathrm{COOH}$ on single crystal silicon substrate. WSM and ASM were adsorbed on such substrate to prepare specific templates. SEM and XRD results showed that, calcite aggregates were formed on -OH surface, surface with $-\mathrm{NH}_{2}$ had no influence on crystal polymorph, only calcite was precipitated, a small amount of vaterites were formed on $-\mathrm{COOH}$ surface due to the acidic electrostatic adsorption (Figure 14).

Calcium carbonate depositions on templates in vitro, of which carp lapillus WSM and ASM adsorbed on modified single crystal silicon substrate, were characterized to have different crystal morphologies. WSM of lapillus (aragonite) on $-\mathrm{NH}_{2}$ and $-\mathrm{COOH}$ templates could induce aragonite crystals, while amorphous calcium carbonate was also observed in the first 5 minutes. ASM of lapillus (aragonite) on $-\mathrm{NH}_{2}$ and $-\mathrm{COOH}$ templates could induce perfect needle-like aragonite particles, which were similar to the aragonite sticks in natural lapillus, but ACC was not found in the process. These results revealed that WSM and ASM of lapillus have different effects in the mineralization process: ASM could mediate perfect crystals compared with WSM, but it did not have the size-mediation effect as WSM did. All the results above explained that the formation of calcium carbonate crystals in lapillus is a very complex process in which different kinds on protein matrices combined and functioned. While, when ASM 
and WSM of carp asteriscus (vaterite) adsorbed on the modified silicon substrate, the deposited crystal particles were similar to those on template without any protein, they are calcite particles with only a few vaterite ones (Figure 15). Why WSM and ASM of asteriscus did not show the mediating effect, the possible reason might lies in the absence of AIM during the extraction process, on which WSM and ASM would adsorb, so as to affect the mineralization process of calcium carbonate.

In order to further study different effects of WSM and ASM, only WSM and ASM of asteriscus were added into the solution without templates. SEM results showed that almost all the crystals were vaterites, there was a little difference in crystal morphology between the vaterites induced by WSM and ASM respectively, as showed in Figure 16, the possible reason lies in different effects on the growth rate of a-axis and c-axis.

\subsection{Natural biomineral templates}

Qiao Li (Qiao, 2008) chose the fresh cross-section of nacre surface of freshwater lustrous pearls (aragonite) as templates without any additives in solutions. XPS results showed that the surface is mainly composed of organic matrix particles, AFM micrograph showed its size of $70 \mathrm{~nm}$. The deposition proved that the formation process was a complex and multistep one, from an ACC layer (Figure 17), iso-oriented nano-stacks to hexagonal aragonite tablets (Figure 18). The result not only proved the existence of ACC in aragonite formation process, but also verified that organic matrices could induce the same calcium carbonate crystal polymorph in vitro as in vivo. 
Similar experiments were carried out by $\mathrm{Li}$ Zhuo (Li, 2008), and the templates were the fresh cross-section of lapillus and asteriscus. SEM and XRD showed that perfect aragonite formed on the surface of lapillus (aragonite), and perfect vaterite crystals formed on the surface of asteriscus (vaterite) without any additive in solutions, similar to the crystal polymorphs in natural carp otolith. Calcium carbonate crystal depositions on lapillus templates with lapillus WSM or ASM in solutions were all tested to be aragonite ones, and their morphologies were both similar to that without any additives (Figure 19). While, when adding asteriscus WSM into the system of asteriscus template, vaterite layers were viewed by SEM (Figure 20b), the author deduced that WSM was adsorbed from solution onto vaterite layer, and then induced vaterite formation on another exposed surface. An organic-inorganic complex structure was then formed accordingly. When adding asteriscus ASM into the system of asteriscus template, crystal particles formed were more intensive, and the morphology was not the same as those deposited in systems without protein, or with WSM in the solution, it tended to grow platy particles in solution (Figure 20c), rather than spherical ones on the surface of asteriscus.

Another important natural biomineral template used in in vitro mineralization is insoluble matrix. Earlier thoughts about organic mediated calcium carbonate crystalline view it more important for insoluble matrix than soluble matrix. While, Falini et al. (Falini et al., 1996) showed that soluble shell protein matrix can determine the polymorph of crystals grown on a substrate of squid chitin and silkworm fibroin, in contrast to earlier work that polymorph controlled by networks of insoluble protein 
matrix extracted from shells. AIM of aragonite and vaterite pearls were used as templates in in vitro experiments, and results showed that perfect calcite crystals were formed on both two templates. The crystal sizes were all $30 \mu \mathrm{m}$, which showed that AIM alone has no influences on crystal polymorphs or morphologies. The crystals deposited on AIM templates were considered to be formed in solution and then fell onto the template.

\subsection{Other templates}

Construction of organic-inorganic hybrid materials with controlled mineralization analogous to those produced by nature is now of current interest for both organic and inorganic chemists. In order to seek out industrial and technological applications it is necessary to understand the mechanism of the natural biomineralization process. Many templates with different characteristics were used in experiments, and we only introduce some examples so as to expand visual fields.

Amino acid modified calcite substrate was used as templates by Qiao Li et al. (Qiao et al., 2008), and the characteristic of amino acid was able to deposit oriented calcite crystals as showed in Figure 21. The size, distribution and orientation of the calcite crystals deposited on template were in uniform, and the crystal plane exposed was (104). The size and density of the crystals changed in accordance with amino acids.

Jack J. J. M. Donners et al. (Donners et al., 2002) reported a shape-persistent polymeric template composed of alanyl-alaninederived poly(isocyanide)s 1 and 2 , of which the rigid macromolecules possessed a regular distribution of carboxylic 
acid-terminated side chains, and its molecule formula is shown in Figure 22. Small angle x-ray scattering (SAXS) and circular dichroism spectrum (CD) indicated the persistence of the rigid helical structure of the macromolecules under the conditions used for crystallization experiments. It also showed that the presence of $\mathrm{Ca}^{2+}$ ions even stabilized the polymer architecture, probably because complex calcium ions screened the peptide bonds in the polymer side chains from water molecules, thereby prohibiting the slow, but gradual disruption of the hydrogen bonds. The introduction of such polymer into a crystallization solution resulted in the formation of calcite crystals with apple core-type morphology (Figure 23), and the nucleation density was in the range normally observed for Langmuir monolayer templates (Heywood and Mann, 1994), but significantly higher than nucleation densities found for templates in bulk solution. The high nucleation density, the low spread in size, and the absence of rhombohedral crystals suggested that polymer 1 also acts as an efficient nucleator. The formed crystals were elongated along the crystallographic c-axis with three (104) end faces expressed on each side of the crystal (Figure 23c). A model of which the polymer adsorbed on to (011) calcite showing the orientational match between the carboxylate groups of the template and the carbonate ions in the nucleated crystal face, thus inhibited growth in these directions and allowing growth only along the c-axis.

\section{Conclusions}

Calcium carbonate is one of the most common biominerals, its growth is according to a variety of phases and morphologies under different conditions: rhombohedra for calcite, 
needles for aragonite and spherical polycrystalline aggregates for vaterite. The above results showed that the mechanism of growth is affected by ions and molecules as amino acids or proteins. We also showed that they can be influenced by the natural or synthetic (or even inorganic) templates used as substrates. By means of additive proteins or organic templates as support, biological tissues can control the allotropic shape, the morphology and can also stabilize amorphous forms as ACC. Thus, chemistry at ambient temperature plays with additional use of organic molecules to open the door to a much wider range of possible polymorphs. The different mineralization results obtained with different additives and templates on calcium carbonate was listed in Table 1 below. It is not surprising that, when evolution requires precipitating large single crystals calcium carbonate structure, it selects calcite, for transportation or growth, it selects ACC or vaterite.

In nature environment, the formation of $\mathrm{CaCO}_{3}$ is a very complex process, and a joint result of variety additives and templates mediation. In the future studies, we hope that the researches would use the method of in vitro mineralization to produce new materials with unique properties.

\section{Acknowledgement}

Authors would like to acknowledge Dr. Y. H. Gao, Dr. Y. F. Ma, Dr. W. T. Hou, Dr. Z.

Li and Dr. L. Qiao (China) for discussion and comments.

This work was supported by National Basic Research Program of China (2007CB815604), National Natural Science Foundation of China (50772052) and 
Doctor Subject Foundation of the Ministry of Education of China (20070003004). 


\section{References}

Addadi, L., Weiner, S., 1985. Interactions between acidic proteins and crystals: stereochemical requirements in biomineralization. P. Natl. Acad. Sci. USA. 82, 4110-4114.

Aizenberg, J., 2000. Patterned crystallization of calcite in vivo and in vitro. J. Cryst. Growth 211, 143-148.

Ameye, L., De Becker, G., Killian, C., Wilt, F., Kemps, R., Kuypers, S., Dubois, P., 2001. Proteins and saccharides of the sea urchin organic matrix of mineralization: Characterization and localization in the spine skeleton. J. Struct. Biol. 134, 56-66.

Bedouet, L., Schuller, M. J., Marin, F., Milet, C., Lopez, E., Giraud, M., 2001.

Soluble proteins of the nacre of the giant oyster Pinctada maxima and of the abalone Haliotis tuberculata: extraction and partial analysis of nacre proteins. Comp. Biochem. Phys. B 128, 389-400.

Belcher, A. M., Wu, X. H., Christensen, R. J., Hansma, P. K., Stucky, G. D., Morse, D. E., 1996. Control of crystal phase switching and orientation by soluble mollusc-shell proteins. Nature 381, 56-58.

Choi, C.S., Kim, Y.W., 2000. A study of the correlation between organic matrices and nanocomposite materials in oyster shell formation. Biomaterials 21, 213-222.

Davis, M. E., 2004. How life makes hard stuff. Science 305, 480-481.

de Leeuw, N. H., Parker, S. C., 1997. Atomistic simulation of the effect of molecular adsorption of water on the surface structure and energies of calcite surfaces. J.

Chem. Soc.-Faraday Transactions 93, 467-475. 
de Leeuw, N. H., Parker, S. C., 1998. Surface Structure and Morphology of Calcium Carbonate Polymorphs Calcite, Aragonite, and Vaterite: An Atomistic Approach. J. Phys. Chem. B. 102, 2914-2922.

Donners, J. J. J. M., Heywood, B. R., Meijer, E. W., Nolte, R. J. M., Sommerdijk, N. A. J. M., 2002. Control over Calcium Carbonate Phase Formation by Dendrimer/ Surfactant Templates. Chem.- Eur. J. 8, 2561-2567.

Donners, J. J. J. M., Nolte,, R. J. M., Sommerdijk, N. A. J. M., 2002. A Shape-Persistent Polymeric Crystallization Template for $\mathrm{CaCO}_{3}$. J. Am. Chem. Soc., 124, 9700-9701.

Falini, G., 2000. Crystallization of calcium carbonates in biologically inspired collagenous matrices. Int. J. Inorg. Mater. 2, 455-461.

Falini, G., Albeck, S., Weiner, S., Addadi, L., 1996. Control of aragonite or calcite polymorphism by mollusk shell macromolecules. Science 271, 67-69.

Falini, G., Fermani, S., Gazzano, M., Ripamonti, A., 2000. Polymorphism and architectural crystal assembly of calcium carbonate in biologically inspired polymeric matrices. J. Chem. Soc. Dalton 3983-3987.

Feng, Q. L., Pu, G., Pei, Y., Cui, F. Z., Li, H. D., Kim, T. N., 2000. Polymorph and morphology of calcium carbonate crystals induced by proteins extracted from mollusk shell. J. Cryst. Growth 216, 459-465.

Fu, G., Valiyaveettil, S., Wopenka, B., Morse, D. E., 2005. CaCO3 biomineralization: Acidic 8-kDa proteins isolated from aragonitic abalone shell nacre can 
specifically modify calcite crystal morphology. Biomacromolecules 6, 12891298.

Gower, L. A., Tirrell, D. A., 1998. Calcium carbonate films and helices grown in solutions of poly(aspartate). J. Cryst. Growth 191, 153-160.

Guillemet, B., Faatz, M., Grohn, F., Wegner, G., Gnanou, Y., 2006 Nanosized Amorphous Calcium Carbonate Stabilized by Poly(ethylene oxide)-b-poly(acrylic acid) Block Copolymers.Langmuir 22, 1875-1879.

Hang, Y. M., 1994. The geological characteristics and the processing technology of fresh water pearl in Ezbou, Hubei province, PhD Thesis, Guilin University of Technology (GUT) (now Guangxi University) (Guilin) (in Chinese).

Hardikar, V. V., Matijevic, E., 2001. Influence of ionic and nonionic dextrans on the formation of calcium hydroxide and calcium carbonate particles. Colloid. Surface. A $186,23-31$.

Heywood, B. R., Mann, S., 1994. Molecular Construction of Oriented Inorganic Materials: Controlled Nucleation of Calcite and Aragonite under Compressed Langmuir Monolayers. Chem. Mater. 6, 311-318.

Hou, W. T., Feng, Q. L., 2005. A simple method to control the polymorphs of calcium carbonate in $\mathrm{CO}_{2}$-diffusion precipitation. J. Cryst. Growth 282, 214-219.

Hou, W. T., Feng, Q. L., 2006. Morphologies and Growth Model of Biomimetic Fabricated Calcite Crystals Using Amino Acids and Insoluble Matrix Membranes of Mytilus edulis. Cryst. Growth. Des. 6, 1086-1090. 
Hou, W. T., Feng, Q. L., 2006. Morphology and formation mechanism of vaterite particles grown in glycine-containing aqueous solutions. Mat. Sci. Eng. C-Bio. S. 26, 644-647.

Hunter, G.K., 1996. Interfacial aspects of biomineralization. Curr. Opin. Solid St. M. $1,430-435$.

Jiao, Y. F., Feng, Q. L., Li, X. M., 2006. The co-effect of collagen and magnesium ions on calcium carbonate biomineralization. Mat. Sci. Eng. C-Bio. S. 26, 648-652.

Kato, T., 2000. Polymer/Calcium carbonate layered thin-film composites. Adv. Mater. $12,1543-1546$.

Kono, M., Hayashi, N., Samata, T., 2000. Molecular mechanism of the nacreous layer formation in Pinctada maxima. Biochem. Bioph. Res. Co. 269, 213-218.

Kulak, A. N., Iddon, P., Li, Y. T., Armes, S. P., Colfen, H., Paris, O., Wilson, R. M. , Meldrum, F. C., 2007. Continuous Structural Evolution of Calcium Carbonate Particles: A Unifying Model of Copolymer-Mediated Crystallization. J. Am. Chem. Soc. 129, 3729-3736.

Levi, Y., Albeck, S., Brack, A., Weiner, S., Addadi, L., 1998. Control over aragonite crystal nucleation and growth: an in vitro study of biomineralization. Chem.- Eur, J. 4, 389-396.

Li, Z., 2008. Studies on hierarchical structure of otolith and biomineralization mechanism of calcium carbonate controlled by otolith's proteins, $\mathrm{PhD}$ Thesis, Tsinghua University (Beijing) (in Chinese). 
Li, Z., Feng, Q. L., 2007. Analysis of polymorphs of Carp's Otoliths. Rare Metal Mat. Eng. 36, 47-49.

Loste, E., Wilson, R. M., Seshadri, R., Meldrum, F. C., 2003. The role of magnesium in stabilising amorphous calcium carbonate and controlling calcite morphologies. J. Cryst. Growth 254, 206-218.

Lowenstam, H. A., 1981. Minerals formed by organisms. Science 211, 1126.

Mann, S. (Ed.), 2001. Biomineralization: Principles and Concepts in Bioinorganic Materials Chemistry, Oxford University Press, New York , pp. 1.

Mann, S. (Eds.), 1996. Inorganic Materials. Wiley, Chichester, pp. 255.

Mann, S., Archibald, D. D., Didymus, J. M., Douglas, T., Heywood, B. R., Meldrum, F. C., Reeves, N. J., 1993. Crystallization at Inorganic-organic Interfaces: Biominerals and Biomimetic Synthesis. Science 261, 1286-1292.

Mann, S., Heywood, B. R., Rajam, S., Birchall, J. D., 1988. Controlled crystallization of $\mathrm{CaCO} 3$ under stearic acid monolayers. Nature 334, 692-695.

Mann, S., Ozin, G. A., 1996. Synthesis of inorganic materials with complex form. Nature 382, 313-318.

Manoli, F., Dalas, E., 2001. Calcium carbonate crystallization in the presence of glutamic acid. J. Cryst. Growth 222, 293-297.

Marin, F., Corstjens, P., de Gaulejac, B., Vrind-De Jong, E. D., Westbroek, P., 2000. Mucins and molluscan calcification - Molecular characterization of mucoperlin, a novel mucin-like protein from the nacreous shell layer of the fan mussel Pinna nobilis (Bivalvia, Pteriomorphia). J. Biol. Chem. 275, 20667-20675. 
Michenfelder, M., Fu, G., Lawrence, C., Weaver, J. C., Wustman, B. A., Taranto, L., Evans, J. S., Morsel, D. E., 2003. Characterization of two molluscan crystal-modulating biomineralization proteins and identification of putative mineral binding domains. Biopolymers 70, 522-533.

Miyamoto, H., Miyashita, T., Okushima, M., Nakano, S., Morita, T., Matsushiro, A., 1996. A carbonic anhydrase from the nacreous layer in oyster pearls. P. Natl. Acad. Sci. USA. 93, 9657-9660.

Miyashita, T., Takagi, R., Okushima, M., Nakano, S., Miyamoto, H., Nishikawa, E., Matsushiro, A., 2000. Complementary DNA cloning and characterization of pearlin, a new class of matrix protein in the nacreous layer of oyster pearls. Mar. Biotechnol. 2, 409-418.

Natoli A., Wiens M., Schroder Heinz-Christoph, Stifanic M., Batel R., Soldati A. L., Jacob D. E., Muller W. E. G., 2010. Micron. 41, 359-366.

Ogasawara, W., Shenton, W., Davis, S. A., Mann, S., 2000. Template mineralization of ordered macroporous chitin-silica composites using a cuttlebone-derived organic matrix. Chem. Mater. 12, 2835-2837.

Pereira-Mouries, L., Almeida, M. J., Ribeiro, C., Peduzzi, J., Barthelemy, M., Milet, C., Lopez, E., 2002. Soluble silk-like organic matrix in the nacreous layer of the bivalve Pinctada maxima: A new insight in the biomineralization field. Eur. J. Biochem. 269, 4994-5003.

Plummer, L. N., Busenberg, E., 1982. The solubilities of calcite, aragonite and vaterite in $\mathrm{CO}_{2}-\mathrm{H}_{2} \mathrm{O}$ solutions between 0 and $90^{\circ} \mathrm{C}$, and an evaluation of the 
aqueous model for the system $\mathrm{CaCO}_{3}-\mathrm{CO}_{2}-\mathrm{H}_{2} \mathrm{O}$. Geochim. Cosmochim. Ac. 46, 1011-1040.

Pokroy, B., Zolotoyabko, E., 2005. Aragonite growth on single-crystal substrates displaying a threefold axis. Chem. Commun., 16, 2140-2142.

Qiao, L., 2008. Structure of Freshwater Vaterite Pearl and Its Biomineralization Mechanism, PhD Thesis, Tsinghua University (Beijing) (in Chinese).

Qiao, L., Feng, Q. L., Li, Z., Lu, S. S., 2008. Alternate Deposition of Oriented Calcite and Amino Acid Layer On Calcite Substrates. J. Phys. Chem. B 112, $13635-13640$.

Qiao, L., Feng, Q. L., Lu, S. S., 2008. In Vitro Growth of Nacre-like Tablet Forming: From Amorphous Calcium Carbonate, Nanostacks to Hexagonal Tablets. J. Cryst. Growth 8, 1509-1514.

Raz, S , Hamilton, P. C., Wilt, F. H., Weiner, S., Addadi, L., 2003. The transient phase of amorphous calcium carbonate in sea urchin larval spicules: the involvement of proteins and magnesium ions in its formation and stabilization. Adv. Funct. Mater. 13, 480-486.

Samata, T., Hayashi, N., Kono, M., Hasegawa, K., Horita, C., Akera, S., 1999. A new matrix protein family related to the nacreous layer formation of Pinctada fucata. Febs Letters 462, 225-229.

Sarikaya, M., Fong, H., Frech, D. W., Humbert, R., 1999. Biomimetic assembly of nanostructured materials. Bioceramics 293, 83-97. 
Shen, F. H., Feng, Q. L., Wang, C. M., 2002. The modulation of collagen on crystal morphology of calcium carbonate. J. Cryst. Growth 242, 239-244.

Shen, X. Y., Belcher, A. M., Hansma, P. K., Stucky, G. D., Morse, D. E., 1997. Molecular cloning and characterization of lustrin A, a matrix protein from shell and pearl nacre of Haliotis rufescens. J. Biol. Chem. 272, 32472-32481.

Stempfle, P., Pantale, O., Njiwa, R. K., Rousseau, M., Bourrat, E. Lopez, X., 2007. Friction-induced sheet nacre fracture: effects of nano-shocks on cracks location. Int. J. Nanotechnol. 4, 712.

Sudo, S., Fujikawa, T., Nagakura, T., Ohkubo, T., Sakaguchi, K., Tanaka, M., Nakashima, K., Takahashi, T., 1997. Structures of mollusc shell framework proteins. Nature 387, 563-564.

Tong, H., Ma, W. T., Wang, L. L., Wan, P., Hu, J. M., Cao, L. X., 2004. Control over the crystal phase, shape, size and aggregation of calcium carbonate via a 1-aspartic acid inducing process. Biomaterials 25, 3923-3929.

Weiss, I. M., Kaufmann, S., Mann, K., Fritz, M., 2000. Purification and characterization of perlucin and perlustrin, two new proteins from the shell of the mollusc Haliotis laevigata. Biochem. Bioph. Res. Co. 267, 17-21.

Xu, A. W., Dong, W. F., Antonietti, M., Cölfen, H., 2008. Polymorph Switching of Calcium Carbonate Crystals by Polymer-Controlled Crystallization. Adv. Funct. Mater. 18, 1307-1313. 
Zhang, C., Li, S., Ma, Z. J., Xie, L. P., Zhang, R. Q., 2006. A novel matrix protein p10 from the nacre of pearl oyster (Pinctada fucata) and its effects on both $\mathrm{CaCO}_{3}$ crystal formation and mineralogenic cells. Mar. Biotechnol. 8, 624-633.

Zhang, Y., Xie, L. P., Meng, Q. X., Jiang, T. M., Pu, R. L., Chen, L., Zhang, R. Q., 2003. A novel matrix protein participating in the nacre framework formation of pearl oyster, Pinctada fucata. Comp. Biochem. Phys. B 135, 565-573. 
Table 1. Different calcium carbonate mineralization results with different additives

and templates

\begin{tabular}{|c|c|c|}
\hline & Influences & References \\
\hline \multicolumn{3}{|l|}{ Additives } \\
\hline \multirow[t]{4}{*}{ Soluble matrices } & $\begin{array}{l}\text { SM could mediate the same } \mathrm{CaCO}_{3} \text { crystal } \\
\text { polymorphs with the biominerals of which } \\
\text { SM were extracted. }\end{array}$ & $\begin{array}{l}\text { Feng et al., 2000; Belcher et } \\
\text { al., 1996) }\end{array}$ \\
\hline & $\begin{array}{l}\text { IM proteins mainly act as structure frames, } \\
\text { providing nucleation sites for calcium } \\
\text { carbonate crystals while SM proteins control } \\
\text { the polymorphs. }\end{array}$ & $\begin{array}{l}\text { Feng et al., 2000; Belcher et } \\
\text { al., 1996; Falini, 1996; Samata } \\
\text { et al., 1999; Kono et al., } 2000\end{array}$ \\
\hline & $\begin{array}{l}\text { Besides SM, IM could also control calcium } \\
\text { carbonate crystal polymorphs. }\end{array}$ & Falini, 1996 \\
\hline & $\begin{array}{l}\text { New protein matrices extraction method } \\
\text { divided soluble protein matrices into WSM } \\
\text { and ASM. }\end{array}$ & Pereira-Mouries et al., 2002 \\
\hline \multirow[t]{2}{*}{ Amino acids } & $\begin{array}{l}\text { Glycine could mediate vaterites, probably by } \\
\text { changing the activation energy of } \mathrm{CaCO}_{3} \\
\text { nucleation. }\end{array}$ & Hou and Feng, 2006 \\
\hline & $\begin{array}{l}\text { Glutamic acid and aspartic acid are both } \\
\text { acidic amino acids, could induce vaterite } \\
\text { growth in solution, they could also influence } \\
\text { crystal morphology. }\end{array}$ & $\begin{array}{l}\text { Tong et al., 2004; Manoli and } \\
\text { Dalas, 2001; Hou and Feng, } \\
2006\end{array}$ \\
\hline \multirow[t]{3}{*}{$\begin{array}{l}\text { Magnesium ions } \\
\text { and collagen }\end{array}$} & $\begin{array}{l}\mathrm{Mg}^{2+} \text { can replace } \mathrm{Ca}^{2+} \text { in calcite, in } \\
\text { conditions of high } \mathrm{Mg} / \mathrm{Ca} \text { ratio, calcite } \\
\text { nucleation would be inhibited and aragonite } \\
\text { nucleation would be favored. } \mathrm{Mg}^{2+} \text { could } \\
\text { promote amorphous calcium carbonate } \\
\text { (ACC) formation. }\end{array}$ & $\begin{array}{l}\text { Mann, 2001; Raz et al., 2003; } \\
\text { Loste et al., } 2003\end{array}$ \\
\hline & $\begin{array}{l}\text { Collagen does not change the polymorph of } \\
\text { calcium carbonates, calcite growth is more } \\
\text { and more inhibited as collagen concentration } \\
\text { increasing, and the morphology changes } \\
\text { with the collagen concentration. }\end{array}$ & Shen et al., 2002 \\
\hline & $\begin{array}{l}\text { Collagen had a promotional effect on } \\
\text { magnesium ions in controlling the } \\
\text { polymorph of } \mathrm{CaCO} 3 \text { crystals. }\end{array}$ & Jiao et al., 2006 \\
\hline $\begin{array}{l}\text { Non-biological } \\
\text { macromolecules }\end{array}$ & $\begin{array}{l}\text { Using different additives, such as } \\
\text { poly-aspartic acid; poly-aspartic acid and } \\
\text { poly-glutamic acid gels; chitin, poly(acrylic } \\
\text { acid) and } \mathrm{Mg}^{2+} \text {; dextran, scientists } \\
\text { successfully produced calcite crystals with }\end{array}$ & $\begin{array}{l}\text { Gower and Tirrell, 1998; } \\
\text { Falini, 2000; Falini et al., } \\
\text { 2000; Kato, 2000; Hardikar } \\
\text { and Matijevic, 2001 }\end{array}$ \\
\hline
\end{tabular}




\begin{tabular}{|c|c|c|}
\hline & $\begin{array}{l}\text { spiral holes on the surface; calcite, aragonite } \\
\text { and vaterite crystals with certain } \\
\text { orientations; aragonite double-layered } \\
\text { composite film } \text { et al. }\end{array}$ & \\
\hline & $\begin{array}{l}\text { DHBCs were also used: PEO-b-PAA could } \\
\text { stabilize spherical ACC particles; } \\
\text { PEO-b-PNaSS could affect calcite particle } \\
\text { morphology change. }\end{array}$ & $\begin{array}{l}\text { Guillemet et al., 2006; Kulak } \\
\text { et al., } 2007\end{array}$ \\
\hline \multicolumn{3}{|l|}{ Templates } \\
\hline $\begin{array}{l}\text { Self-assembled } \\
\text { monolayers } \\
\text { (SAMs) }\end{array}$ & $\begin{array}{l}\text { Micropatterned self-assembled monolayers } \\
\text { (SAMs) with special X-terminal exposed } \\
\left(\mathrm{X}=\mathrm{COOH}, \mathrm{SO}_{3} \mathrm{H}, \mathrm{OH}\right) \text { was used to } \\
\text { synthesize patterned calcite films of which } \\
\text { the nucleation, size and orientation of the } \\
\text { crystals could be controlled. }\end{array}$ & Aizenberg, 2000 \\
\hline \multirow[b]{2}{*}{$\begin{array}{l}\text { Glass, single } \\
\text { crystal silicon } \\
\text { and modified } \\
\text { single crystal } \\
\text { silicon }\end{array}$} & Glass surface may induce aragonite crystals. & Hou and Feng, 2005 \\
\hline & $\begin{array}{l}-\mathrm{OH},-\mathrm{NH}_{2} \text { and }-\mathrm{COOH} \text { grafted single } \\
\text { crystal silicon were used to study the effects } \\
\text { of different radical: calcite aggregates were } \\
\text { formed on -OH surface, surface with }-\mathrm{NH}_{2} \\
\text { had no influence on crystal polymorph; a } \\
\text { small amount of vaterites were formed on } \\
\text {-COOH surface. WSM and ASM from } \\
\text { otoliths adsorbed silicon substrates were also } \\
\text { used: those of lapillus could induce } \\
\text { aragonites, while those from asteriscus had } \\
\text { little crystal polymorph effect. }\end{array}$ & $\mathrm{Li}, 2008$ \\
\hline \multirow[t]{3}{*}{$\begin{array}{l}\text { Natural } \\
\text { biomineral }\end{array}$} & $\begin{array}{l}\text { Fresh cross-section of nacre surface of } \\
\text { freshwater lustrous pearls (aragonite) as } \\
\text { templates was used: the formation process } \\
\text { was developed from an ACC layer, } \\
\text { iso-oriented nano-stacks to hexagonal } \\
\text { aragonite tablets. }\end{array}$ & Qiao, 2008 \\
\hline & $\begin{array}{l}\text { The fresh cross-section of lapillus and } \\
\text { asteriscus were used: perfect aragonite } \\
\text { formed on the surface of lapillus (aragonite), } \\
\text { and perfect vaterite crystals formed on the } \\
\text { surface of asteriscus (vaterite). }\end{array}$ & $\mathrm{Li}, 2008$ \\
\hline & $\begin{array}{l}\text { Acid insoluble matrix (AIM) of aragonite } \\
\text { and vaterite pearls were used and perfect } \\
\text { calcite crystals were formed on both two } \\
\text { templates, which showed no influences on } \\
\text { crystal polymorphs or morphologies. }\end{array}$ & Qiao, 2008 \\
\hline Other templates & Amino acid modified calcite substrate was & Qiao et al., 2008 \\
\hline
\end{tabular}




\begin{tabular}{|l|l|l|}
\hline & $\begin{array}{l}\text { used and calcite crystals with uniform size, } \\
\text { distribution and orientation were deposited. }\end{array}$ & \\
\cline { 2 - 3 } & $\begin{array}{l}\text { A shape-persistent polymeric template } \\
\text { composed of alanyl-alaninederived } \\
\text { poly(isocyanide)s was used and calcite } \\
\text { crystals with apple core-type morphology } \\
\text { were formed. }\end{array}$ & Donners et al., 2002 \\
\hline
\end{tabular}




\section{Figure Captions}

Figure 1. Asteriscus morphology (a) and its vaterite composition: Raman spectrum (b) and micro-area XRD (c) (image courtesy Li Z.).

Figure 2. Photos of fresh water vaterite pearls (a), aragonite pearls (b) and semimat pearls (c) (image courtesy Qiao L.).

Figure 3. SEM morphologies of the calcium carbonate crystals grown on single-crystal silicon ( $\left.\begin{array}{lll}0 & 0 & 1\end{array}\right)$, (a) with soluble proteins from nacreous layer, crystal size 20-30 $\mu \mathrm{m}$ (b) with soluble proteins from prismatic layer, crystal size 8-15 $\mu \mathrm{m}$.

SEM morphologies of the calcium carbonate crystals grown on insoluble proteins from nacreous layer, (c) with soluble proteins from nacreous layer, crystal size 5-10 $\mu \mathrm{m}$ (d) with soluble proteins from prismatic layer, crystal size10-15 $\mu \mathrm{m}$ (image courtesy Feng Q. L.).

Figure 4. SEM morphologies of vaterite crystals obtained by the titration and diffusion method.

(a) $[\mathrm{Gly}]=10^{-3} \mathrm{M}$, dripping velocity $15 \mathrm{ml} / \mathrm{min}, \mathrm{C}$ : calcite, $\mathrm{V}$ : vaterite;

(b) $[\mathrm{Gly}]=10^{-3} \mathrm{M}$, dripping velocity $2 \mathrm{ml} / \mathrm{min}$; sample without glycine showed similar result;

(c) $[\mathrm{Gly}]=10^{-3} \mathrm{M}$, diffusion method, almost all vaterite;

(d) Detailed structure of vaterite, composed of oviods with a size about $2 \mu \mathrm{m}$ (image 
courtesy Hou W. T.).

Figure 5. Calcium carbonate precipitates grown in the presence of $\mathrm{Mg} / \mathrm{Ca}=2: 1$ and the addition of $35 \mathrm{nmol} \mathrm{mL} \mathrm{m}^{-1}$ of a,c) macromolecules extracted from $48 \mathrm{~h}$ fully developed spicules after fertilization; b,d) macromolecules extracted from $72 \mathrm{~h}$ fully developed spicules after fertilizatio. a,b) SEM images; c,d) images taken under cross-polarized light. The particles in (d) are single crystals, which extinguish each in a different position of the polarizer, while the particle in (c) has homogeneous extinction in all positions (It is found that extracts of spicules from $48 \mathrm{~h}$ prism stage embryos induce the formation of a transient ACC phase, whereas extracts from spicules of $72 \mathrm{~h}$ plutei induce the formation of single calcite crystals) (image courtesy Raz S.).

Figure 6. SEM morphologies of the calcite crystals precipitated in the solution. (a) Rhombohedral calcite crystal grown in the solution without collagen. (b) Rhombohedral calcite crystal with little disfigurement, collagen concentration: $0.1 \mathrm{~g} / \mathrm{l}$. (c) Overgrown calcite crystal with new planes, collagen concentration: $0.1-5 \mathrm{~g} / \mathrm{l}$. (d) Multiple layer calcite crystal with thinner layer thickness, collagen concentration: 5-10 g/l. (e) Some planes with flower-like pattern, collagen concentration: 5-10 g/l. (f) Spherulitic calcite aggregates at higher collagen concentration: >10g/l (image courtesy Shen F. H.).

Figure 7. SEM morphologies of the calcium carbonate crystals precipitated in the solution, collagen concentration: $0.1 \mathrm{~g} / \mathrm{l}$. (a) Irregular rhombohedral calcite crystal 
grown in the solution without magnesium. (b) Irregular lumpish crystals with lamellar growth structure $(\mathrm{Mg} / \mathrm{Ca}: 1)$. (c, d, e) Discoid and dumbbell calcium carbonate crystals. (f) Spherical aragonite crystals at higher magnesium concentration $(\mathrm{Mg} / \mathrm{Ca}$ : 5). (g) Spherical aragonite crystals with more regular shape $(\mathrm{Mg} / \mathrm{Ca}$ : 5 , collagen concentration: $0.4 \mathrm{~g} / \mathrm{l})$. (h) Aragonite crystals with needle shape without collagen (Mg/Ca: 5) (image courtesy Jiao Y. F.).

Figure 8. SEM of the unusual morphologies of $\mathrm{CaCO}_{3}$ minerals grown in solutions of poly(aspartate). The control synthesis, not shown here, yields rhombohedra calcite crystals that are typically 20 to $60 \mu \mathrm{m}$ in size. (A) A calcite crystal containing spiral pits resulting from the addition of $0.5 \mu \mathrm{g} / \mathrm{ml} \operatorname{poly}(\alpha, \mathrm{L}$-aspartate) to the crystallizing dish. Bar=100 $\mu \mathrm{m}$ (image courtesy Gower L. A.).

Figure 9. SEM image of the cross section of a double-layered composite film consisting of $\mathrm{CaCO}_{3}$ and chitin prepared in the presence of poly(acrylic acid). (image courtesy Kato T.).

Figure 10. SEM of (a) calcium carbonate particles obtained by aging a solution containing $0.25 \mathrm{~mol} \mathrm{dm}^{-3} \mathrm{CaCl}_{2}$ and $0.75 \mathrm{~mol} \mathrm{dm}^{-3}$ urea at $90^{\circ} \mathrm{C}$ for $4 \mathrm{~h}$ (standard condition), and (b) a mixture of calcite, vaterite and aragonite polymorphs obtained in the same system in the presence of $1 \mathrm{wt} \%$ Dex-DEAE-500 (image courtesy Hardikar V. V.).

Figure 11. SEM pictures of ACC precipitated with 1, 5, and 10 ppm of DHBC (image 
courtesy Guillemet B.).

Figure 12. Calcium carbonate crystals precipitated from a solution containing $10 \mathrm{mM}$ $\mathrm{Ca}$ and $\mathrm{PEO}_{22}-\mathrm{PNaStS}_{49}$ at a concentration such that the $[\mathrm{Ca}]:[\mathrm{S}]$ molar ratio (where [S] is the molar concentration of polymerized sulfonate groups) was (a) 250:1, (b) 250:1, (c) 125:1, (d) 20:1, (e) 12.5:1, and (f) 12.5:1 (image courtesy Kulak A. N.).

Figure 13. Patterned crystallization of calcite on micropatterned SAMs consisting of a square array of printed, rapidly nucleating circles (SAMs of $\left.\mathrm{HS}\left(\mathrm{CH}_{2}\right)_{15} \mathrm{CO}_{2} \mathrm{H}\right)$ in a slowly nucleating background (SAMs of HS(CH2)15CH3). (A) Number of crystals per active nucleation region, $\mathrm{n}$, as a function of its size. The value, $\mathrm{n}$, is proportional to the area, $S$, of the active region: $n \cong 16,6,2$ and 1 for $S \cong 2800(d=60 \mu m), 960$ $(\mathrm{d}=35 \mu \mathrm{m}), 320(\mathrm{~d}=20 \mu \mathrm{m})$, and $175 \mu \mathrm{m}(\mathrm{d}=15 \mu \mathrm{m})$. This relationship provides precise control over the nucleation density, by regulating the size of the features in the SAM. (B) Nucleation density and extent of area-selective nucleation as a function of concentration of crystallizing solution. The increase in concentration results in occasional crystallization on the methyl-terminated region, in agreement with the expected decrease in the size of the depletion zone (image courtesy Aizenberg J.).

Figure 14. SEM result of calcium carbonate precipitates grown on the $-\mathrm{OH},-\mathrm{NH}_{2}$ and $-\mathrm{COOH}$ modified surface of single silicon: (a) $-\mathrm{OH}$ modified surface, (b) $-\mathrm{NH}_{2}$ modified surface, (c) - $\mathrm{COOH}$ modified surface (image courtesy Li Z.).

Figure 15. SEM and XRD results of soluble protein matrices mediated $\mathrm{CaCO}_{3}$ 
crystals $(\mathrm{a}, \mathrm{c}) \mathrm{CaCO}_{3}$ crystals formed on modified silicon with WSM in solution; $(\mathrm{b}, \mathrm{d})$ $\mathrm{CaCO}_{3}$ crystals formed on modified silicon with ASM in solution (image courtesy Li Z.).

Figure 16. Morphologies and sketch map of vaterite crystal growth under different protein matrix function (a,c) WSM in solution, (b,d) ASM in solution (image courtesy Li Z.).

Figure 17. Observations of $\mathrm{CaCO}_{3}$ grown on fresh nacre tablets for 5 min. (a) SEM image of the $\mathrm{CaCO}_{3}$ deposition on nacre; (b) the amplified observation of (a); (c) EDS results of nacre with "noodles" depositions, which indicated that these noodles were $\mathrm{CaCO}_{3}$; (d) Raman results of nacre surfaces with and without the early noodles $\mathrm{CaCO}_{3}$ depositions (image courtesy Qiao L.).

Figure 18. SEM images of $\mathrm{CaCO} 3$ grown on nacre surface for different times.

(a) $10 \mathrm{~min}$; (b) $30 \mathrm{~min}$; (c) 1 h; (d) 2 h; (e) 3 h; (f) 10 h (image courtesy Qiao L.).

Figure 19. SEM (a) and XRD (b) result of aragonite crystals on lapillus templates without additive in the solution (image courtesy Li Z.).

Figure 20. SEM results of vaterite crystals on asteriscus templates without additive (a), with WSM (b) and with ASM (c) in the solution (image courtesy Li Z.).

Figure 21. SEM micrographs of calcite tablets and calcite layers deposited on amino 
acid layers. (a) Calcite tablets grown on glutamic acid layer for $1 \mathrm{~h}$; (b) calcite tablets grown on arginine layer for $1 \mathrm{~h}$; (c) the bigger and conjunctive calcite tablets grown on glutamic acid layer for $1.5 \mathrm{~h}$; (d) the calcite layer grown on glutamic acid layer for 2h (image courtesy Qiao L.).

Figure 22. (a) Chemical structures of polymers 1, and 2. (b) CD spectra of aqueous solutions of $1 / \mathrm{Ca}^{2+}\left(\right.$ black) and $2 / \mathrm{Ca}^{2+}\left(\right.$ gray); $\mathrm{Ca}^{2+} /$ repeat unit $=1: 1$, [polymer] $=1.3$ mM (in repeat units) (image courtesy Donners J. J. J. M.).

Figure 23. Scanning electromicrographs of (a) calcite grown in the absence of polymer, $(b, c)$ calcite grown in the presence of polymer 1 , and (d) crystals grown in the presence of polymer 2 (image courtesy Donners J. J. J. M.). 

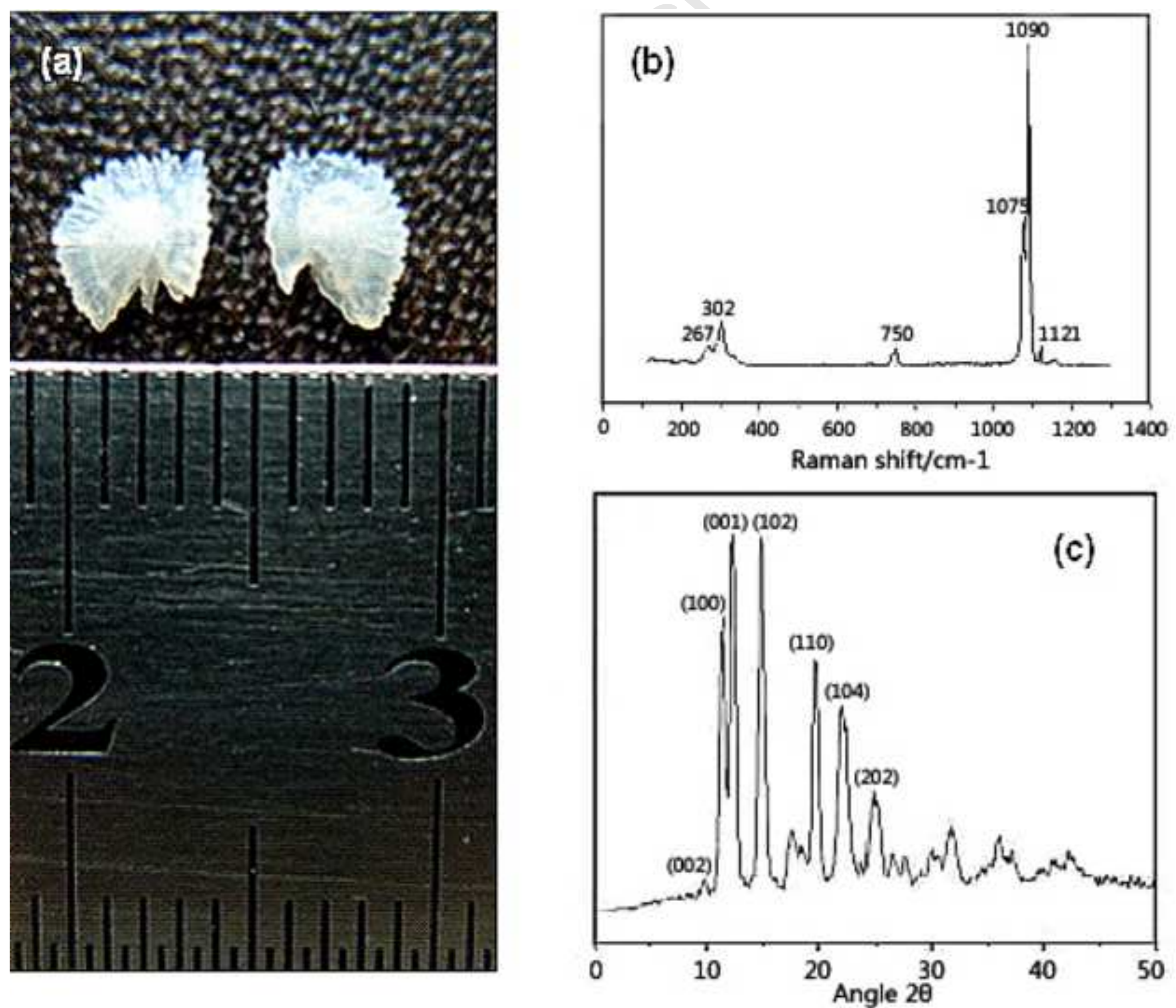

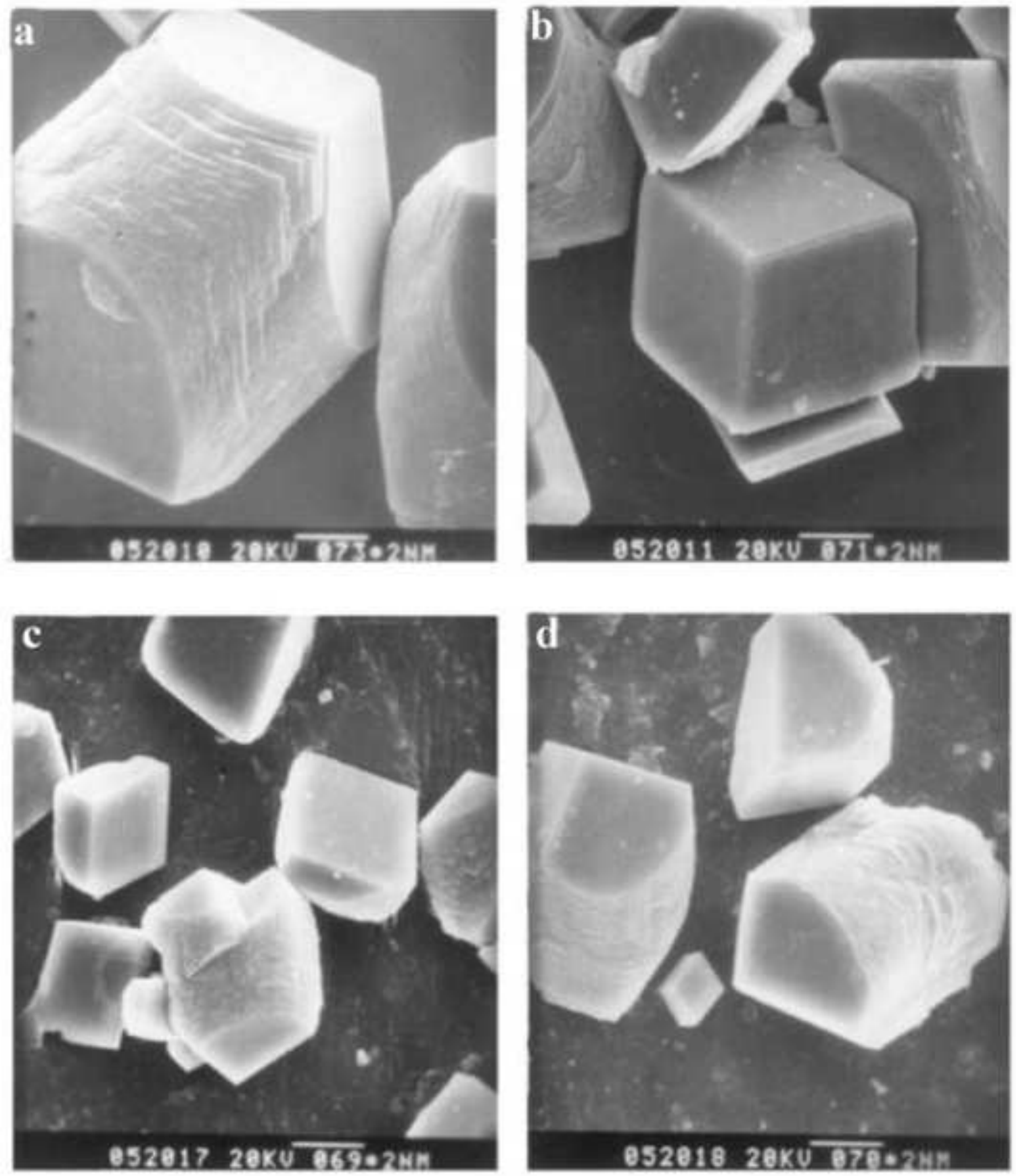

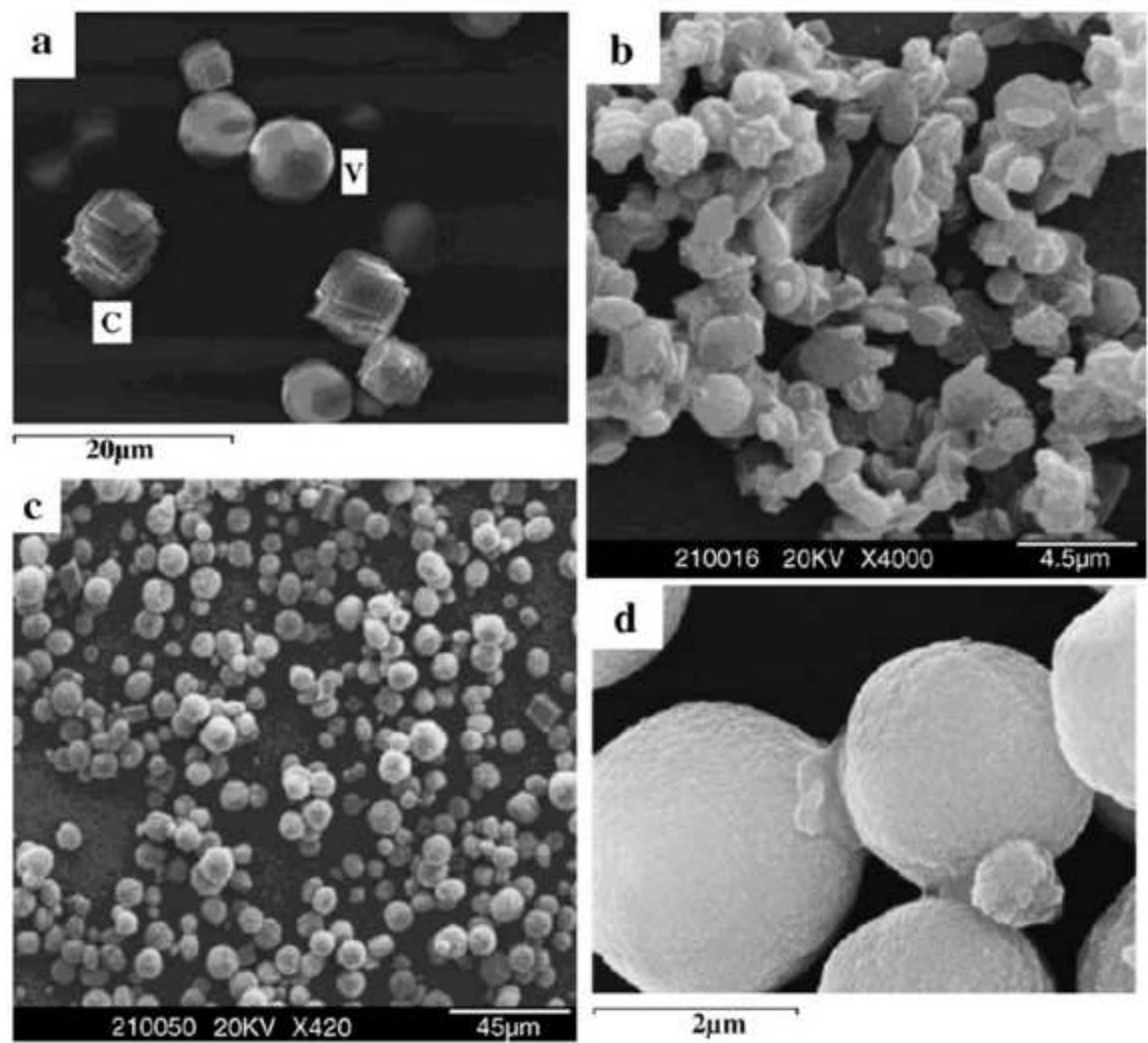


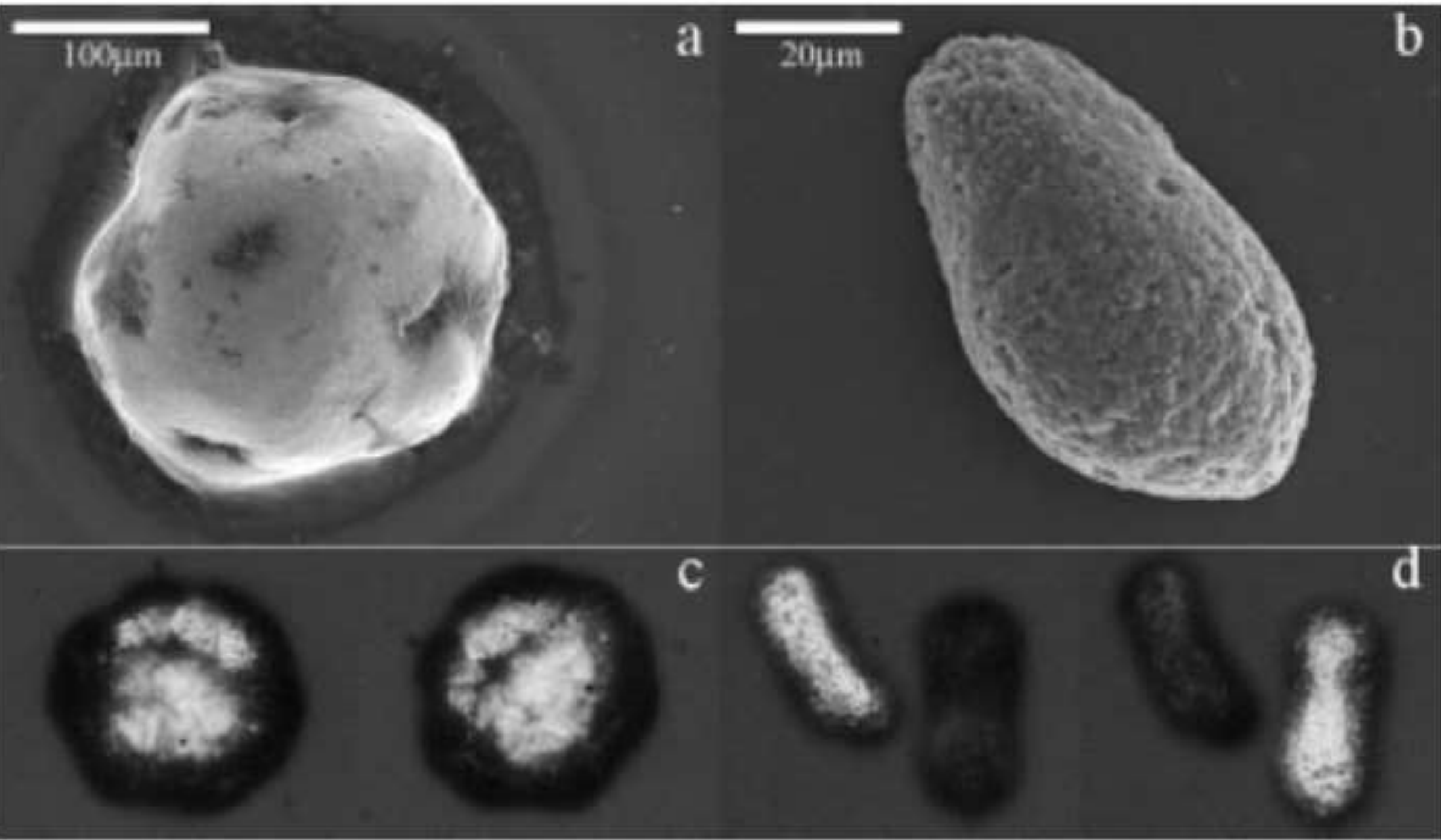




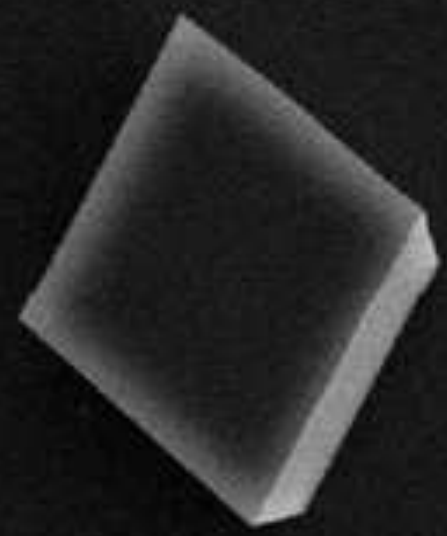

(a) $84860528 \mathrm{kV} \sqrt{949}+2 \mathrm{NH}$
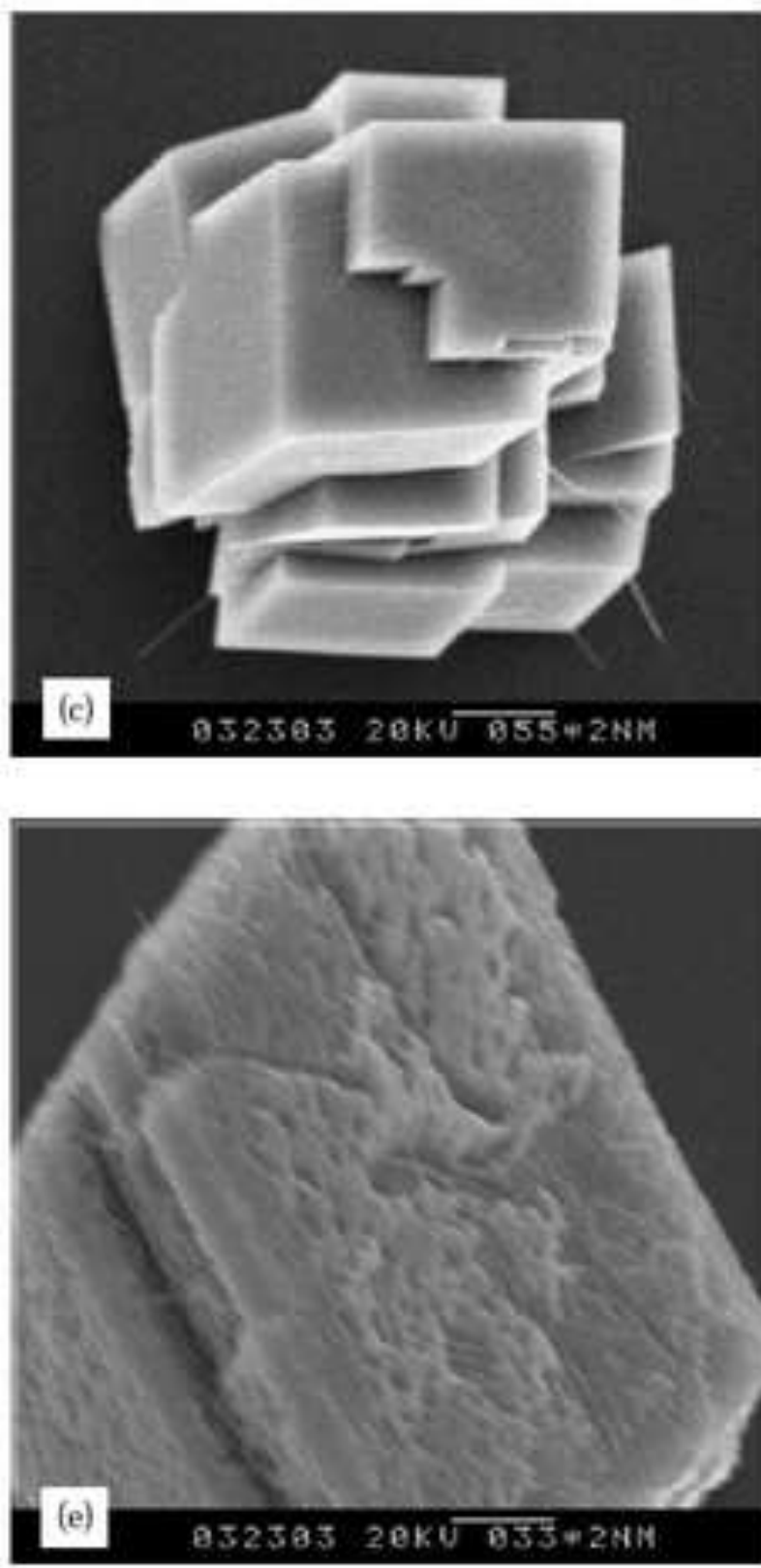

(b)

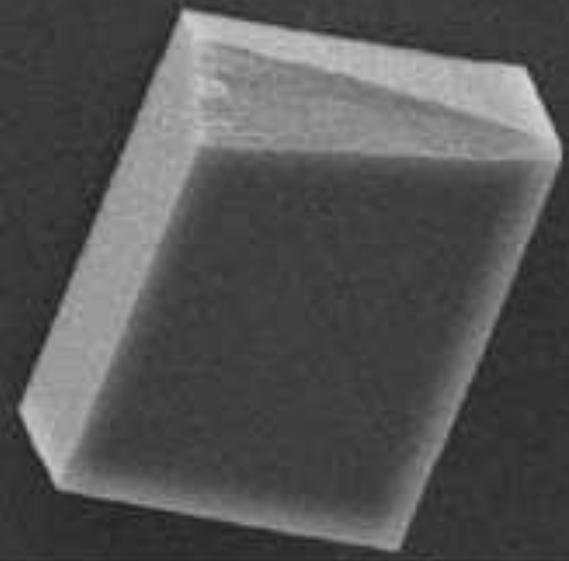

$84069520 K \mathrm{666}+2 \mathrm{HM}$
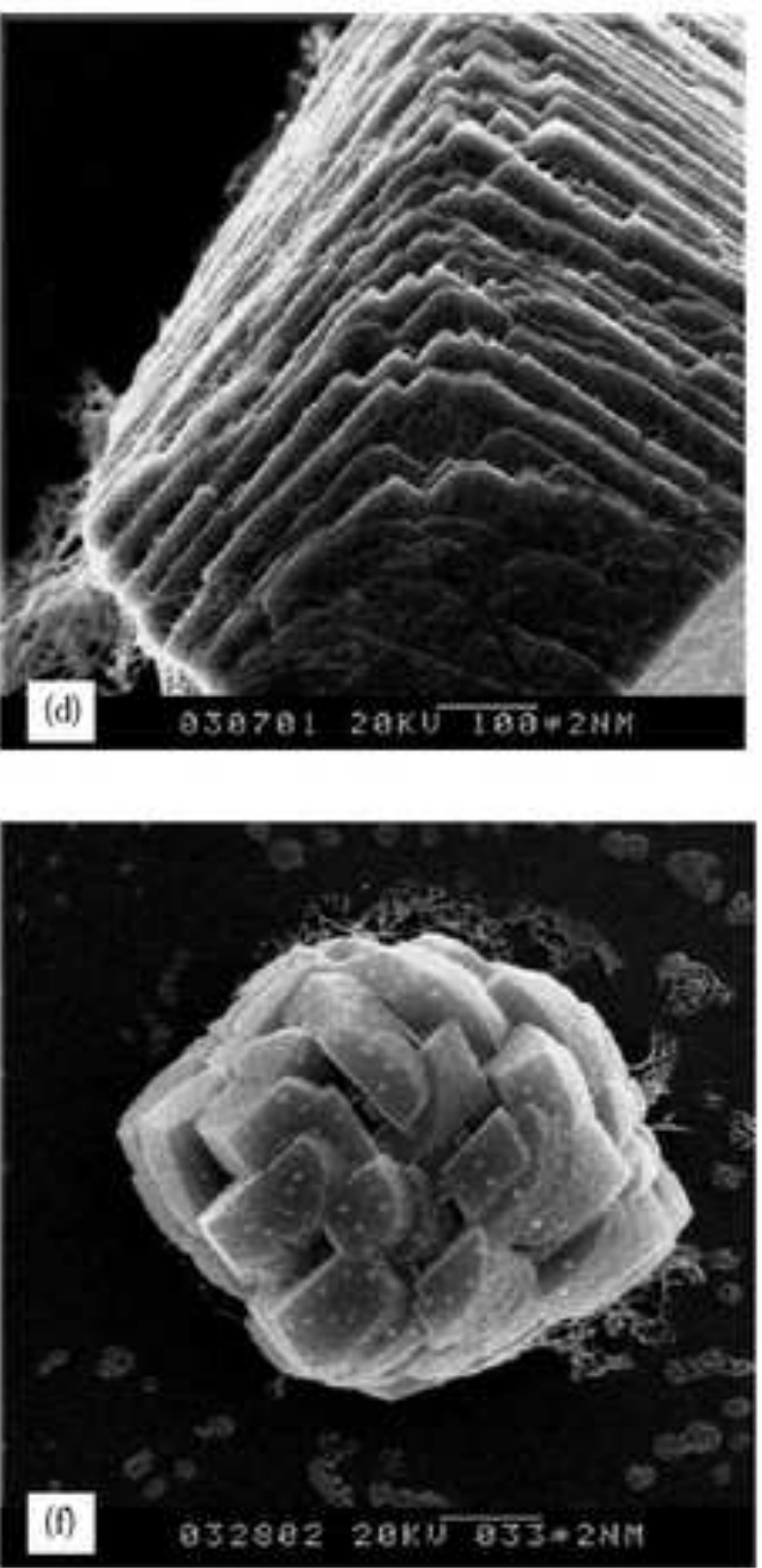

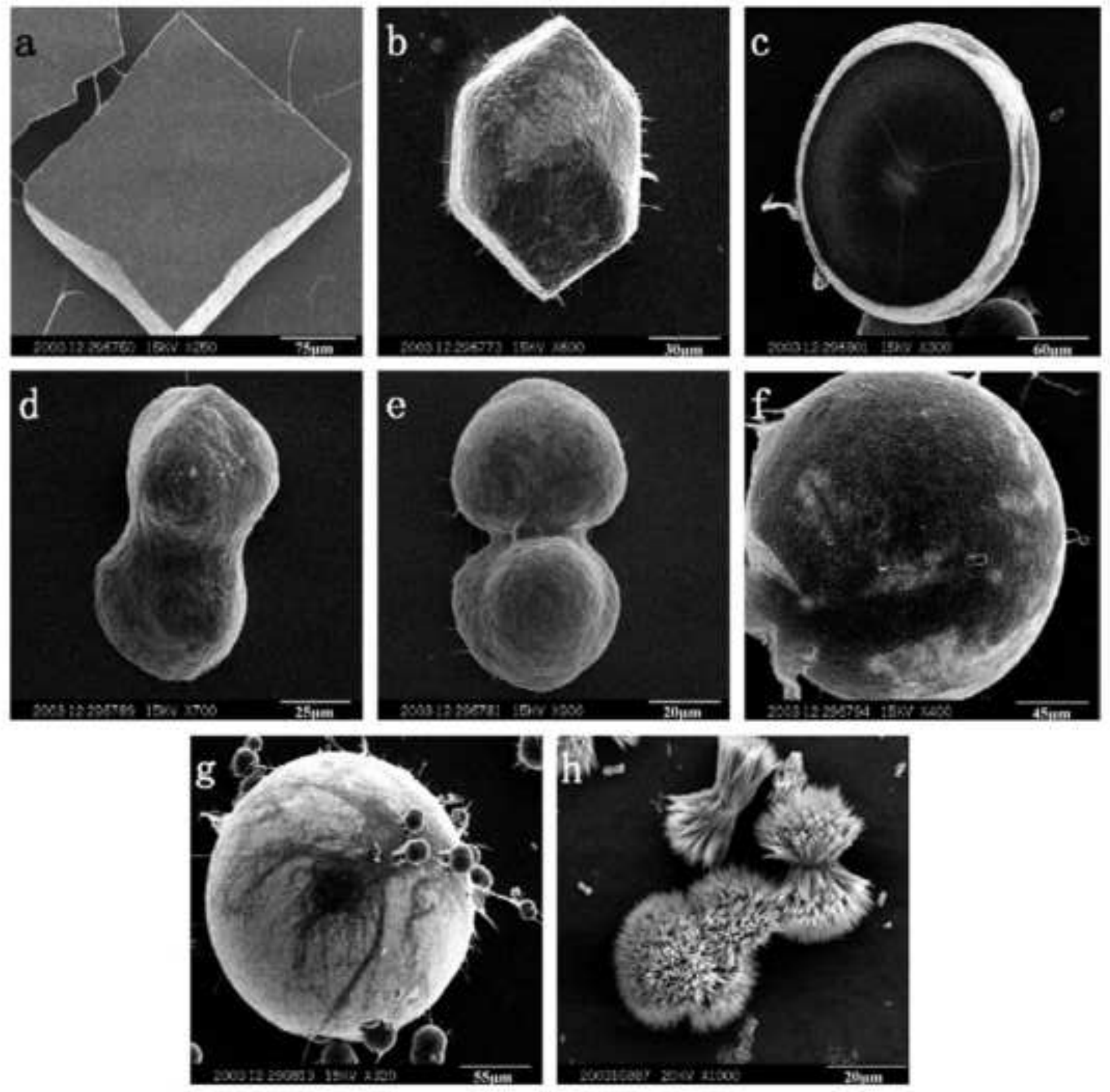


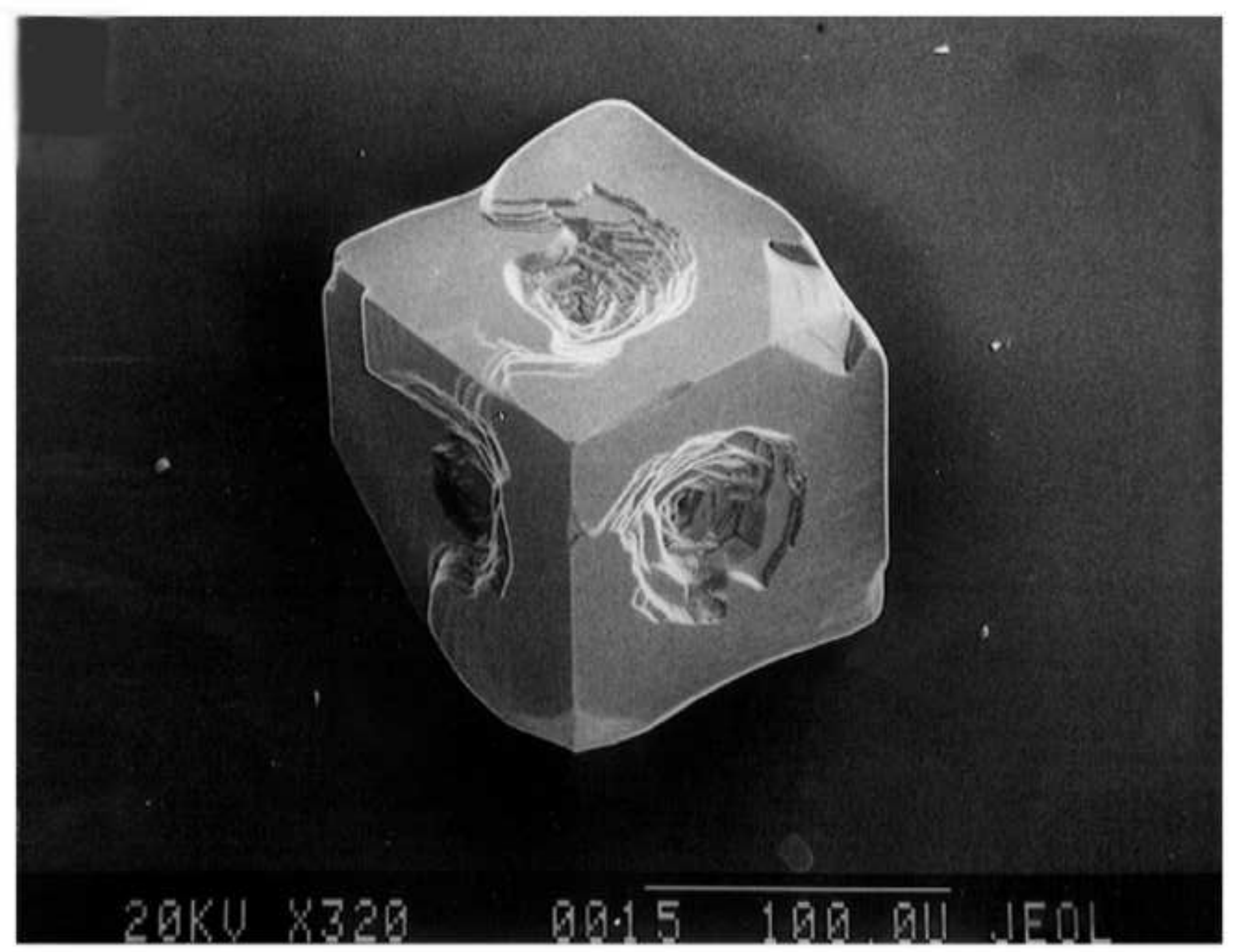




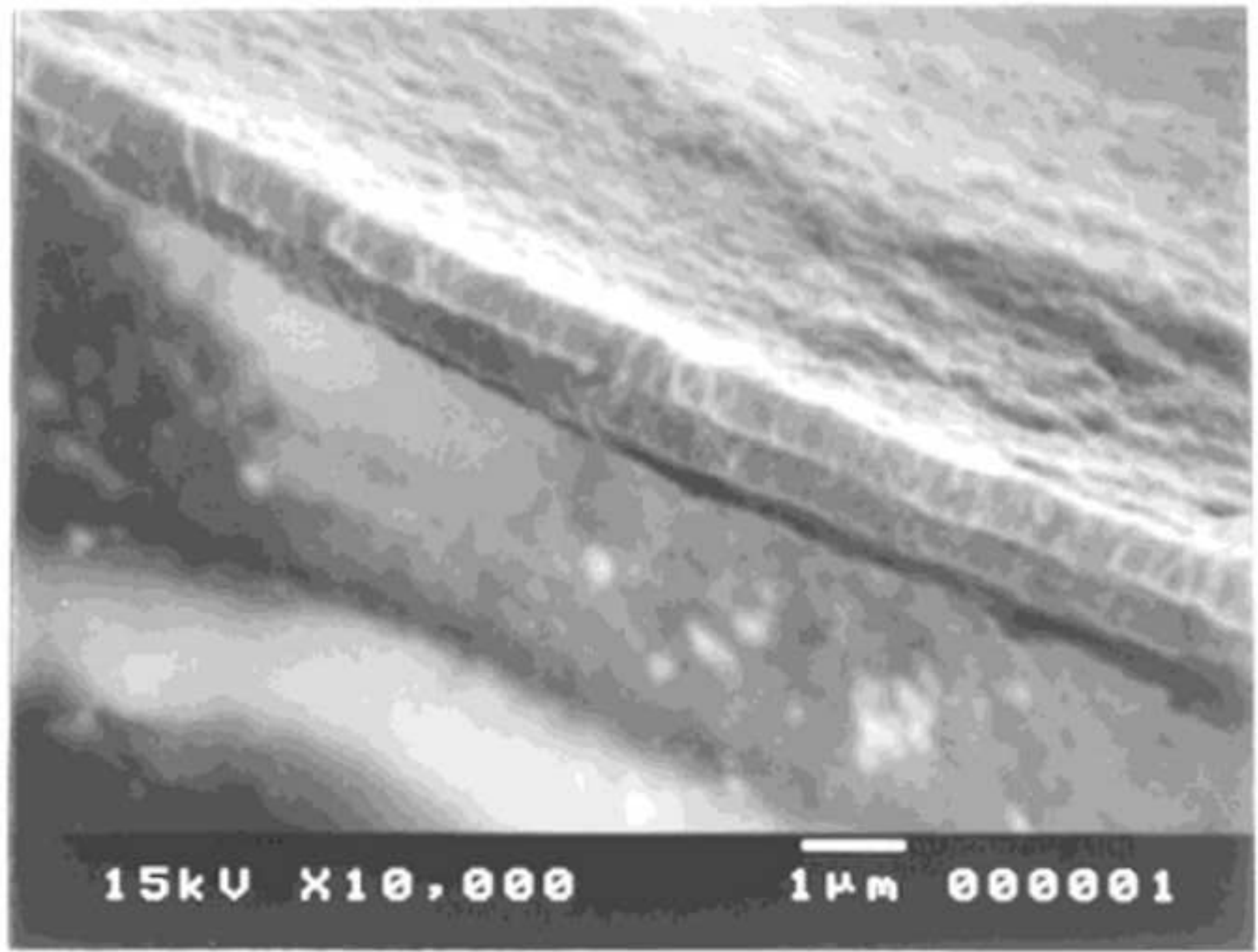



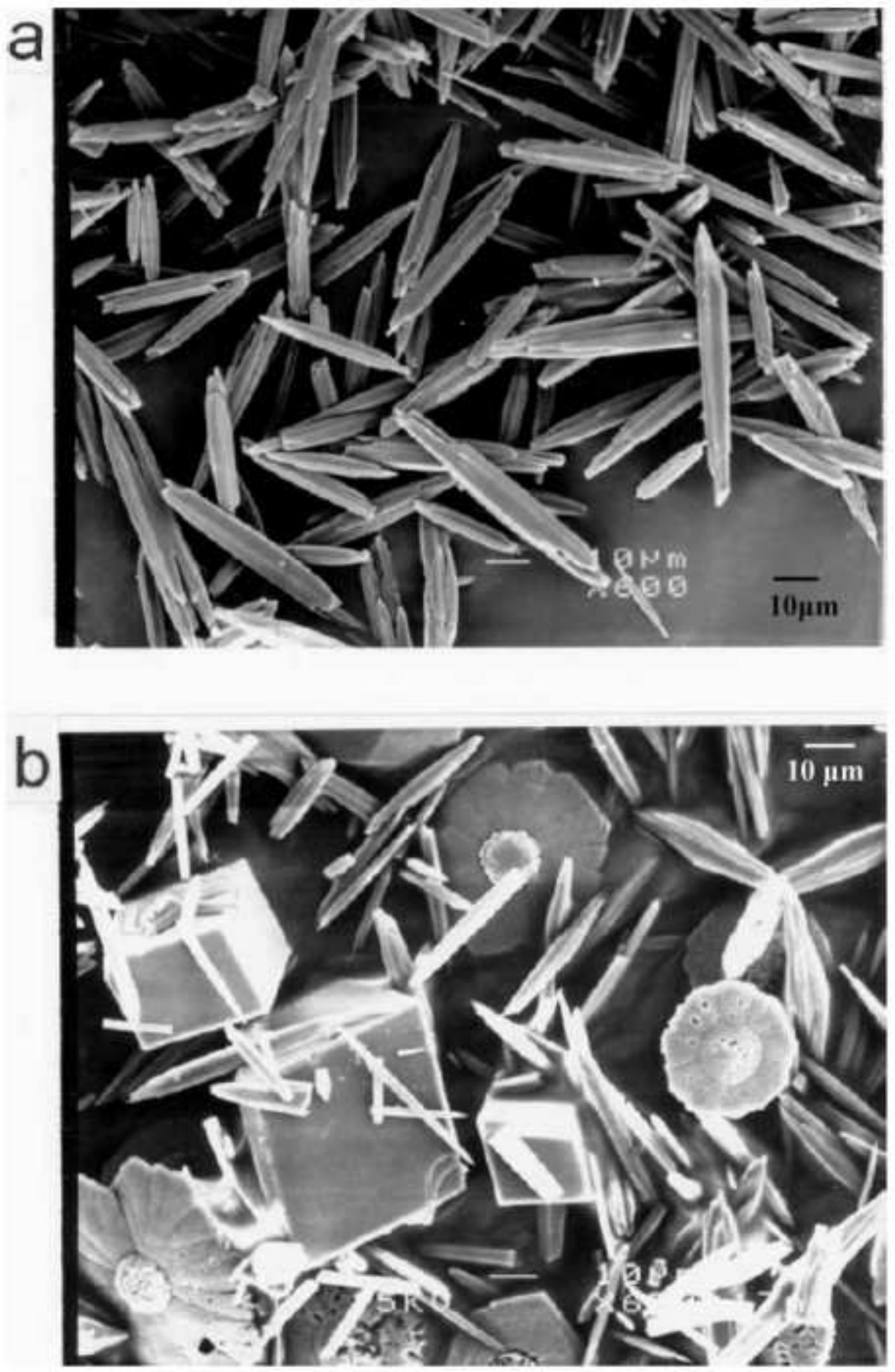


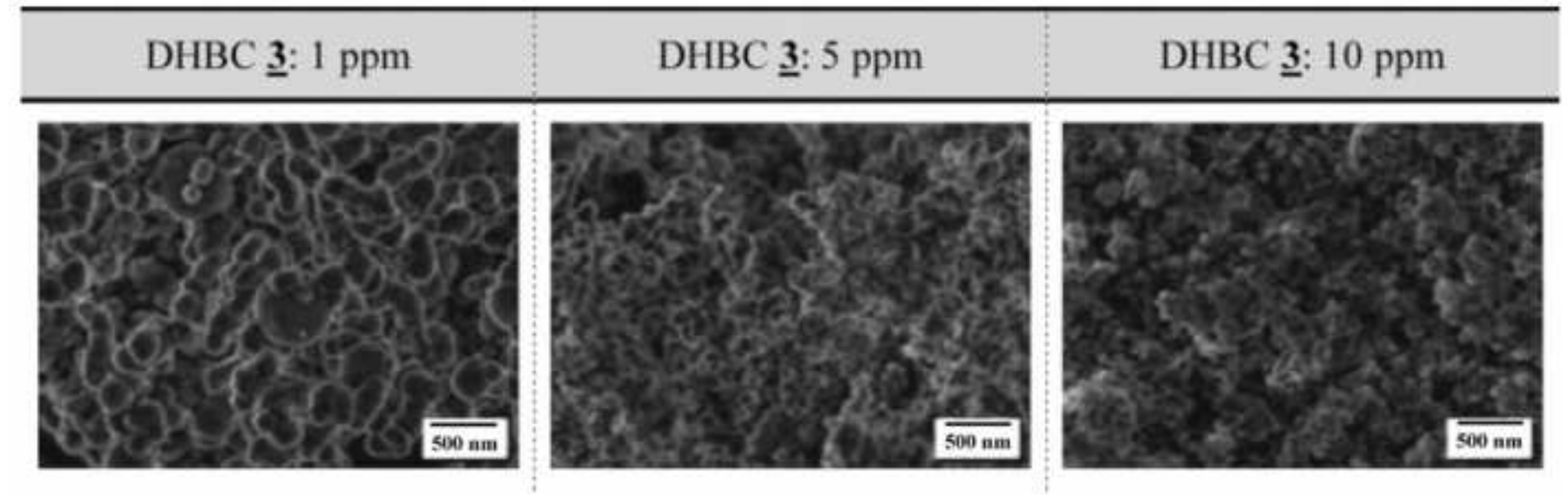



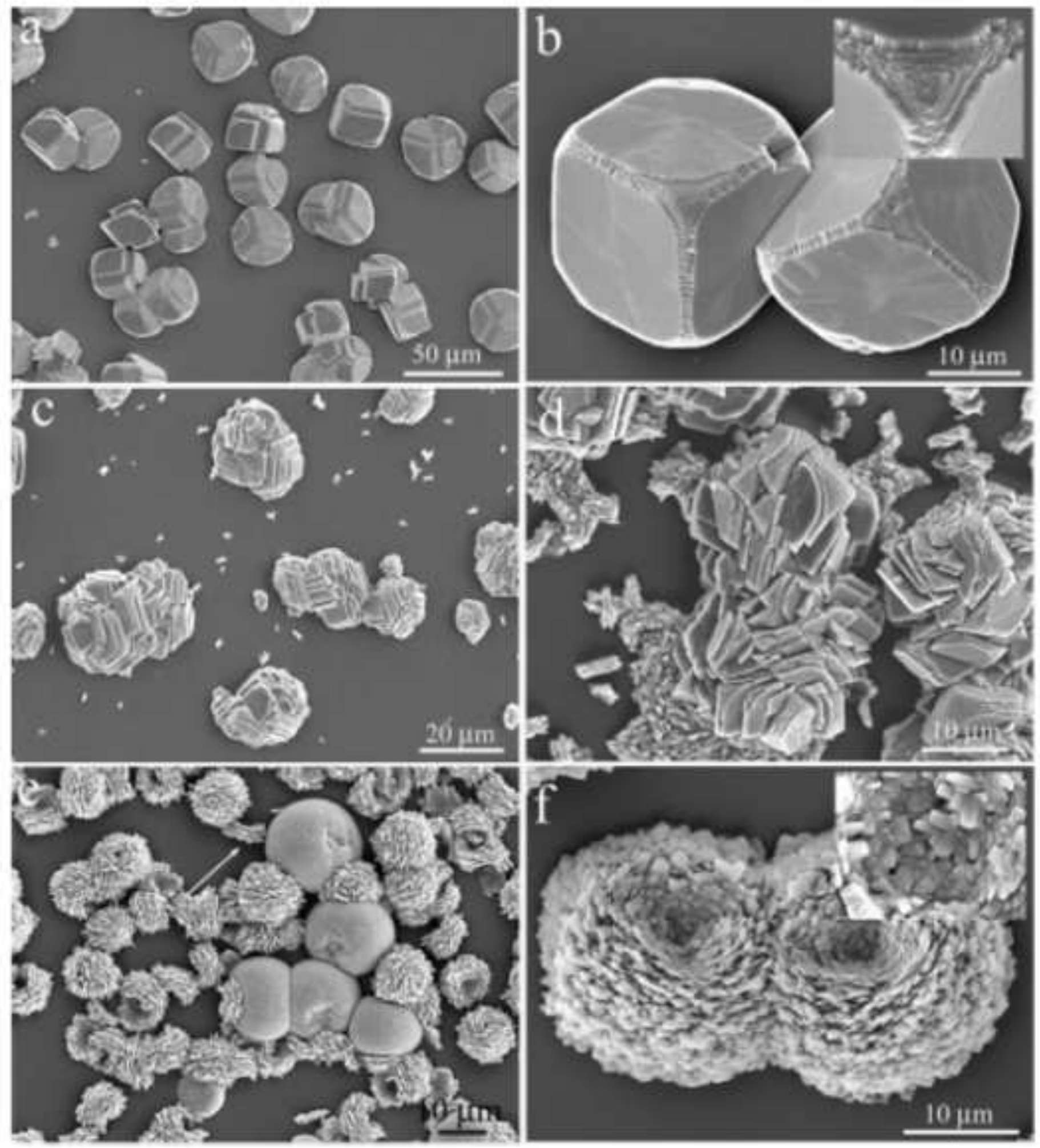

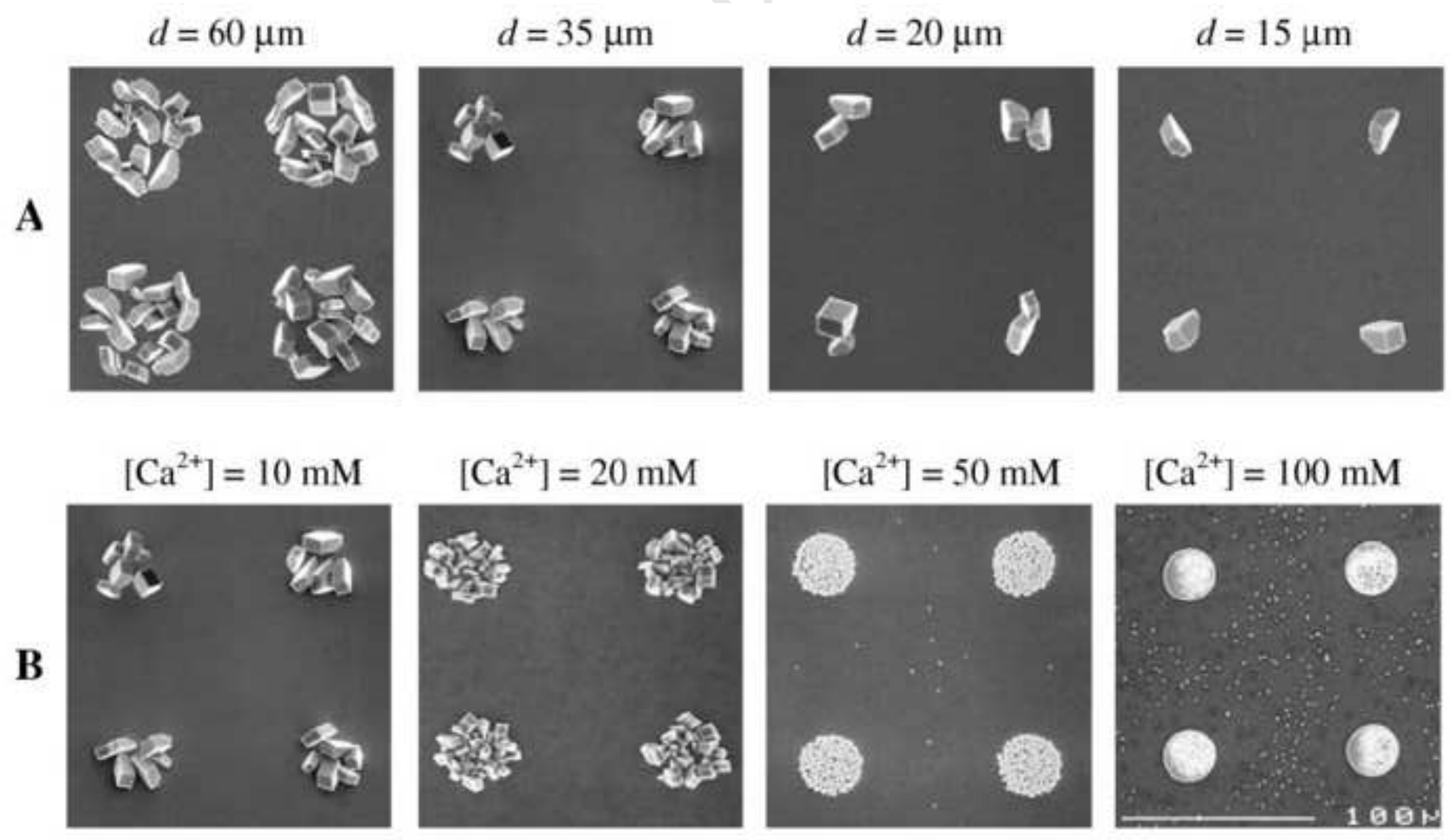


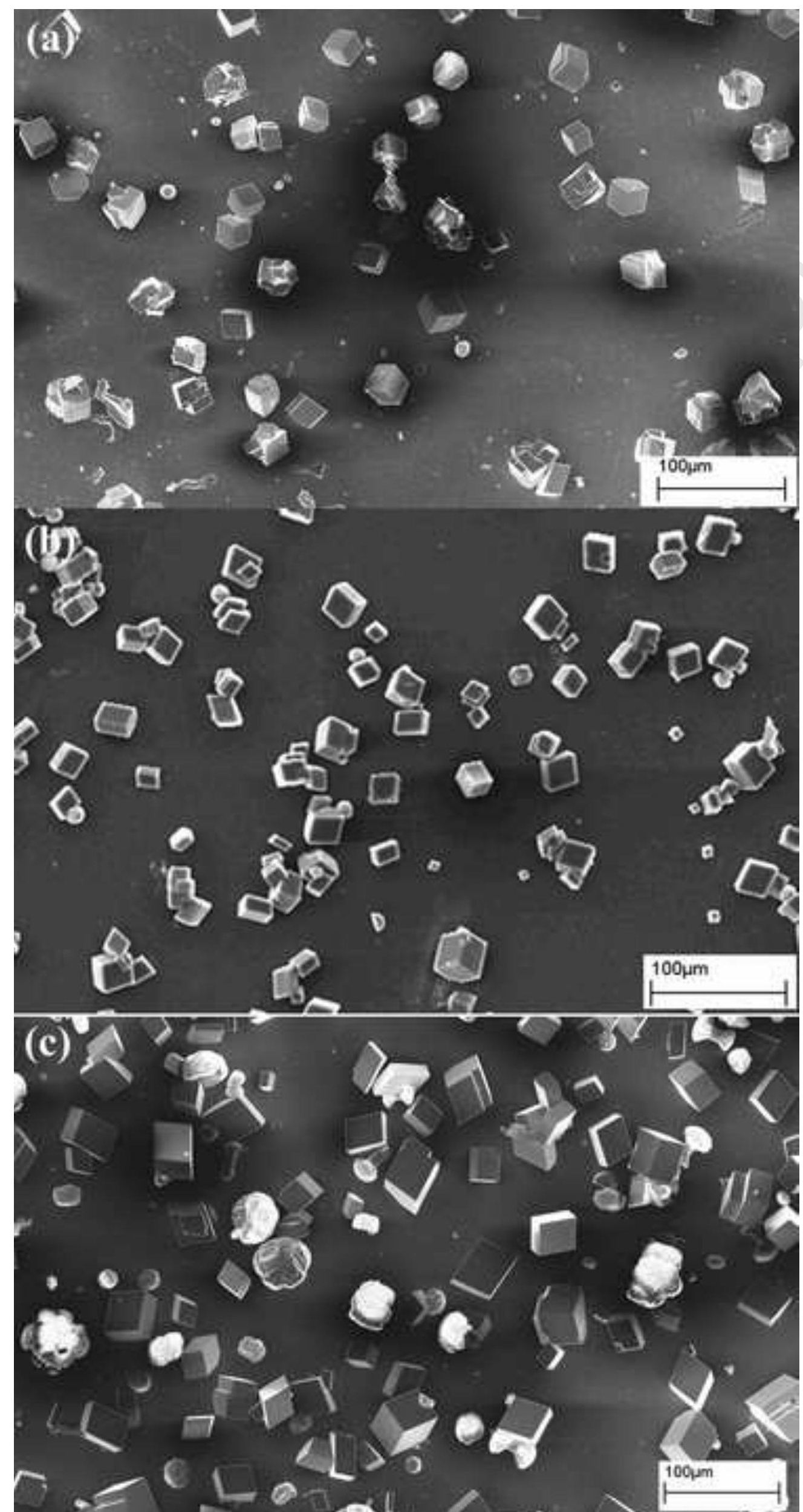



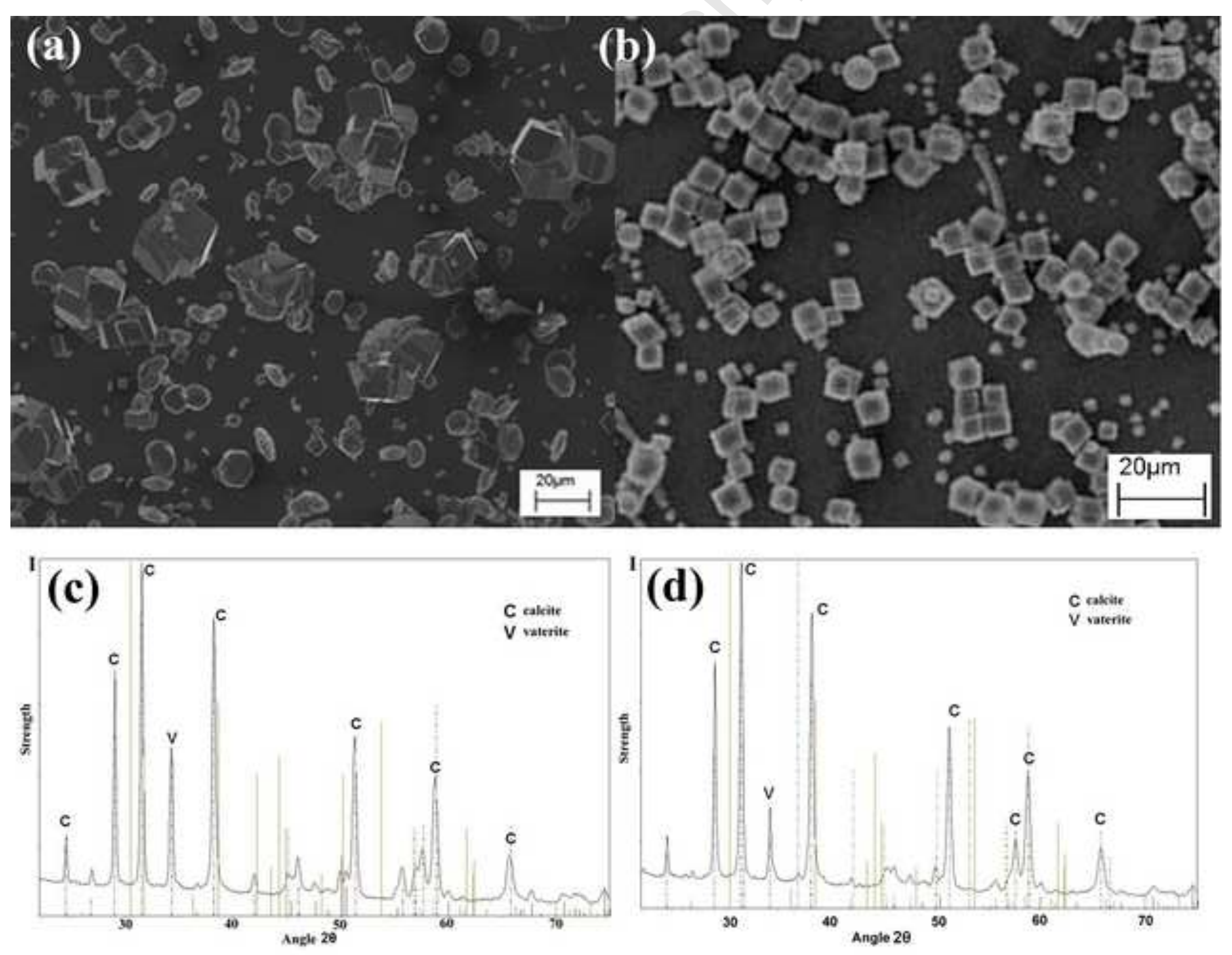


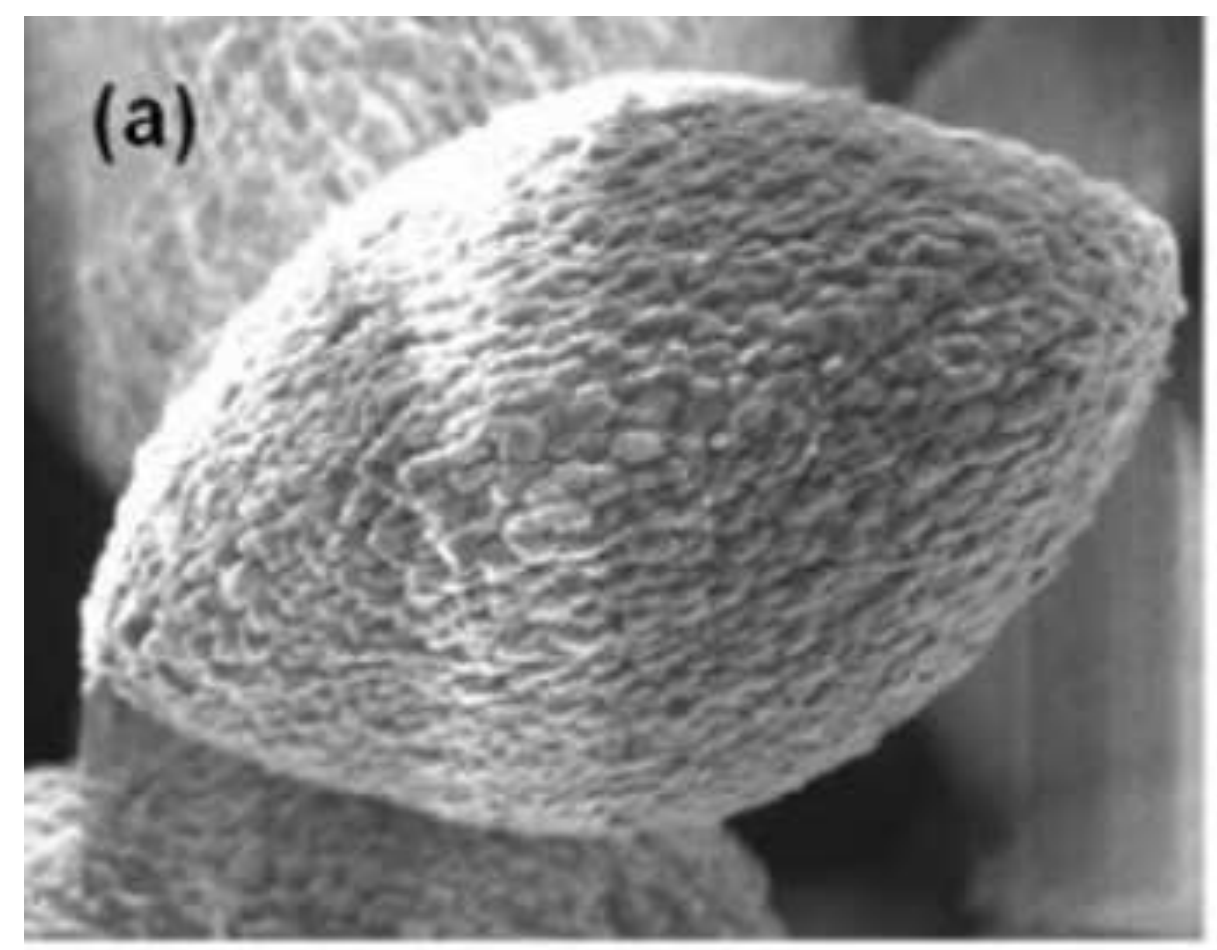

(b)

(c)

(d)
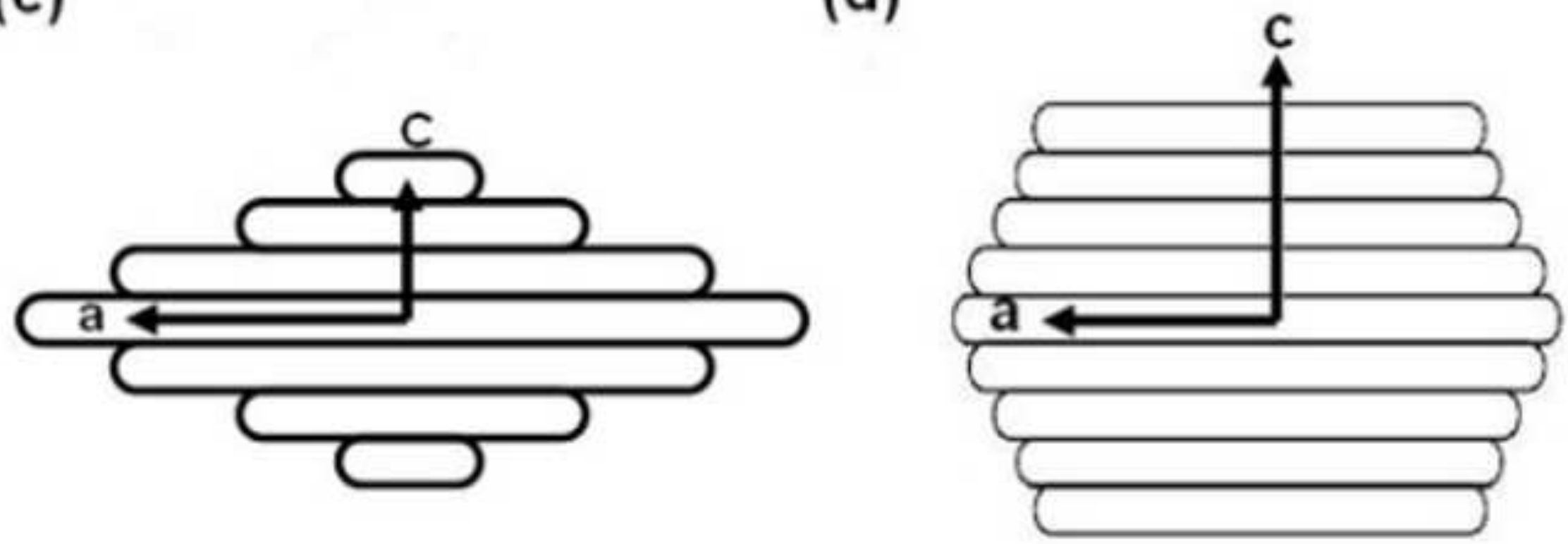


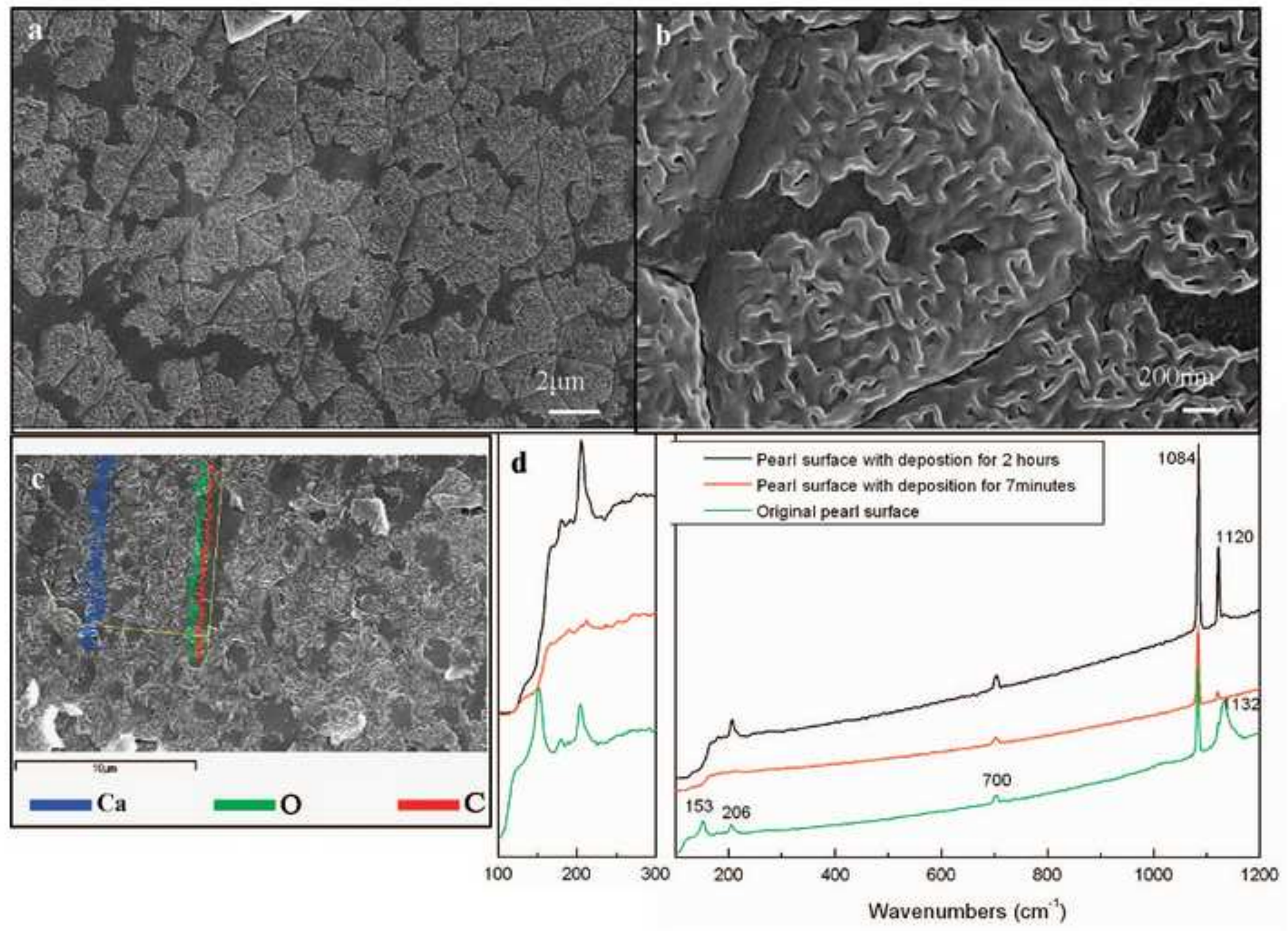




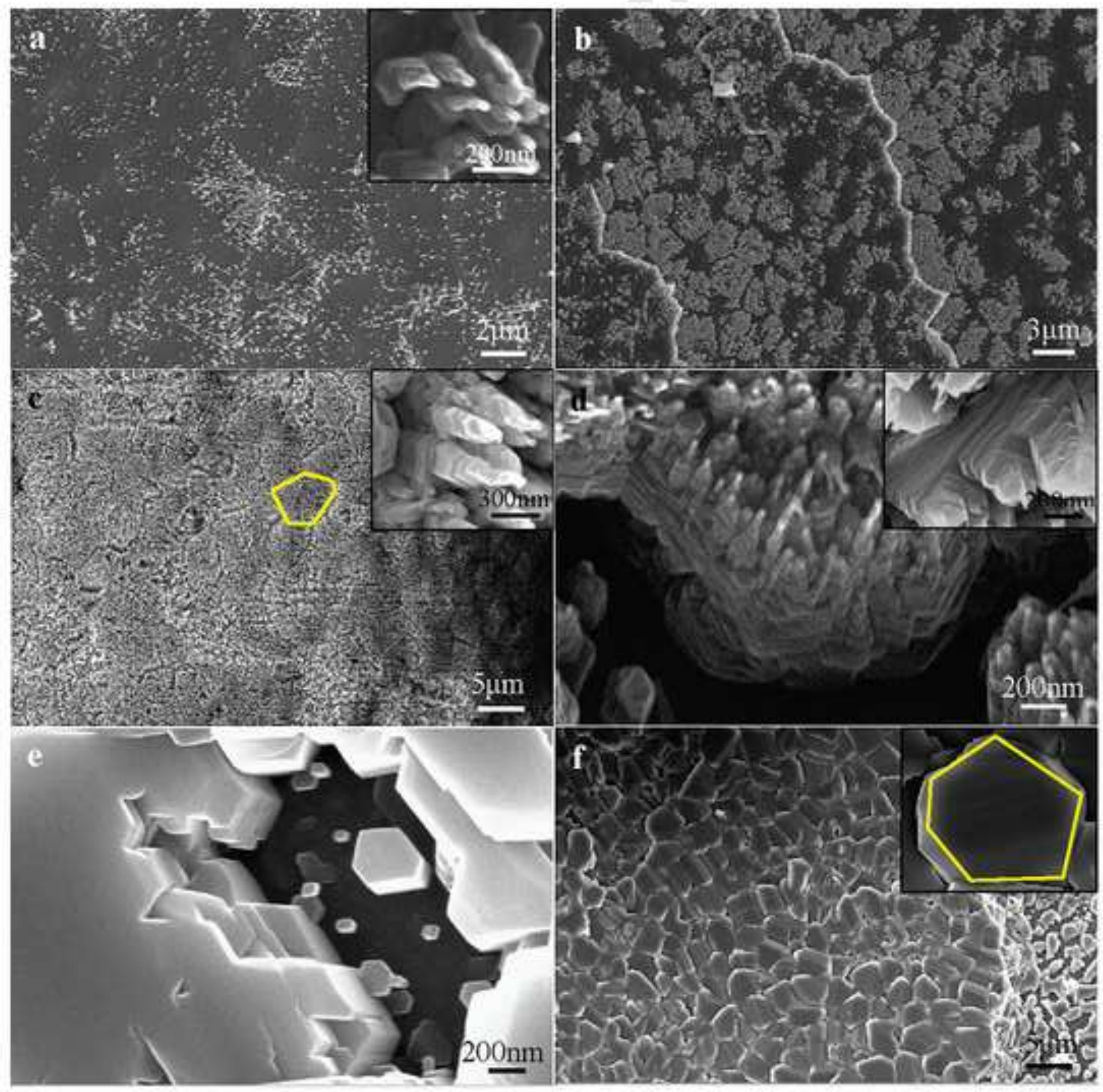



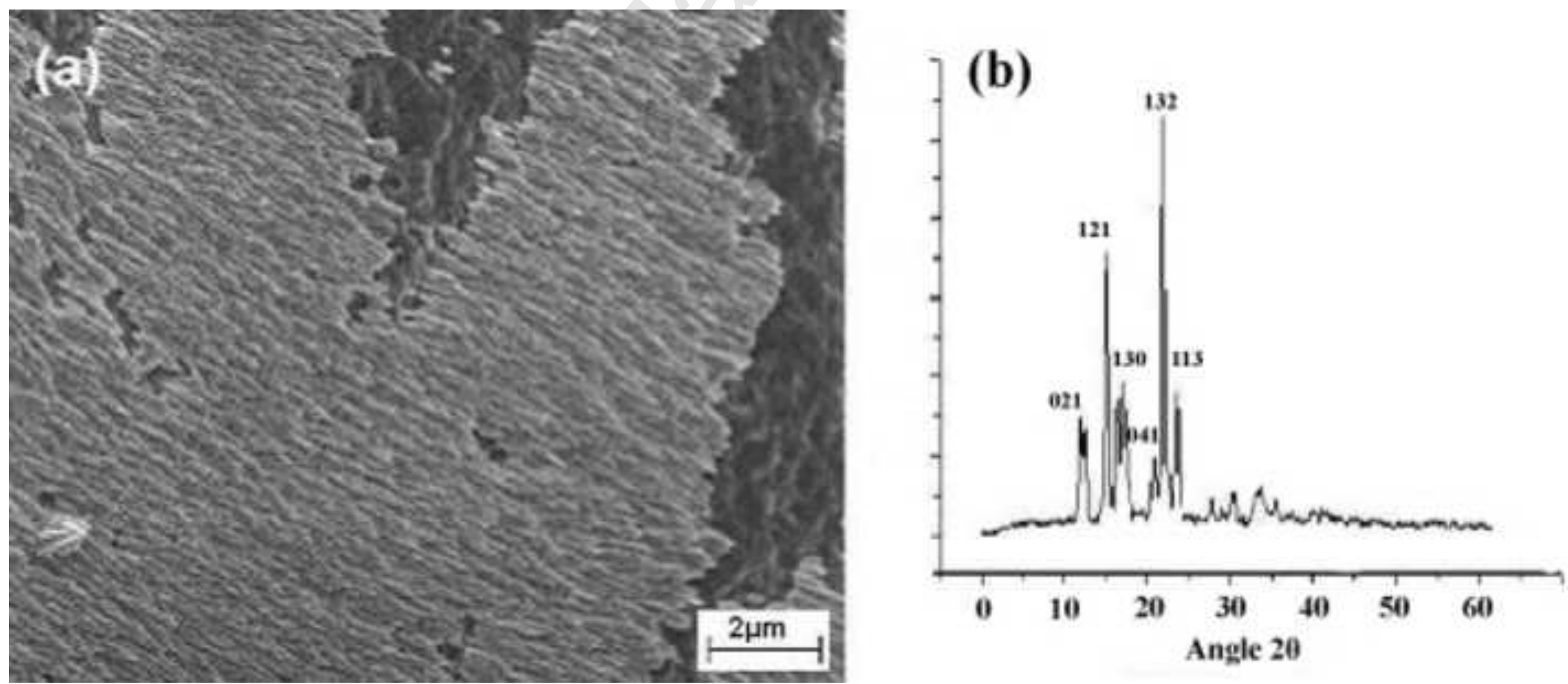

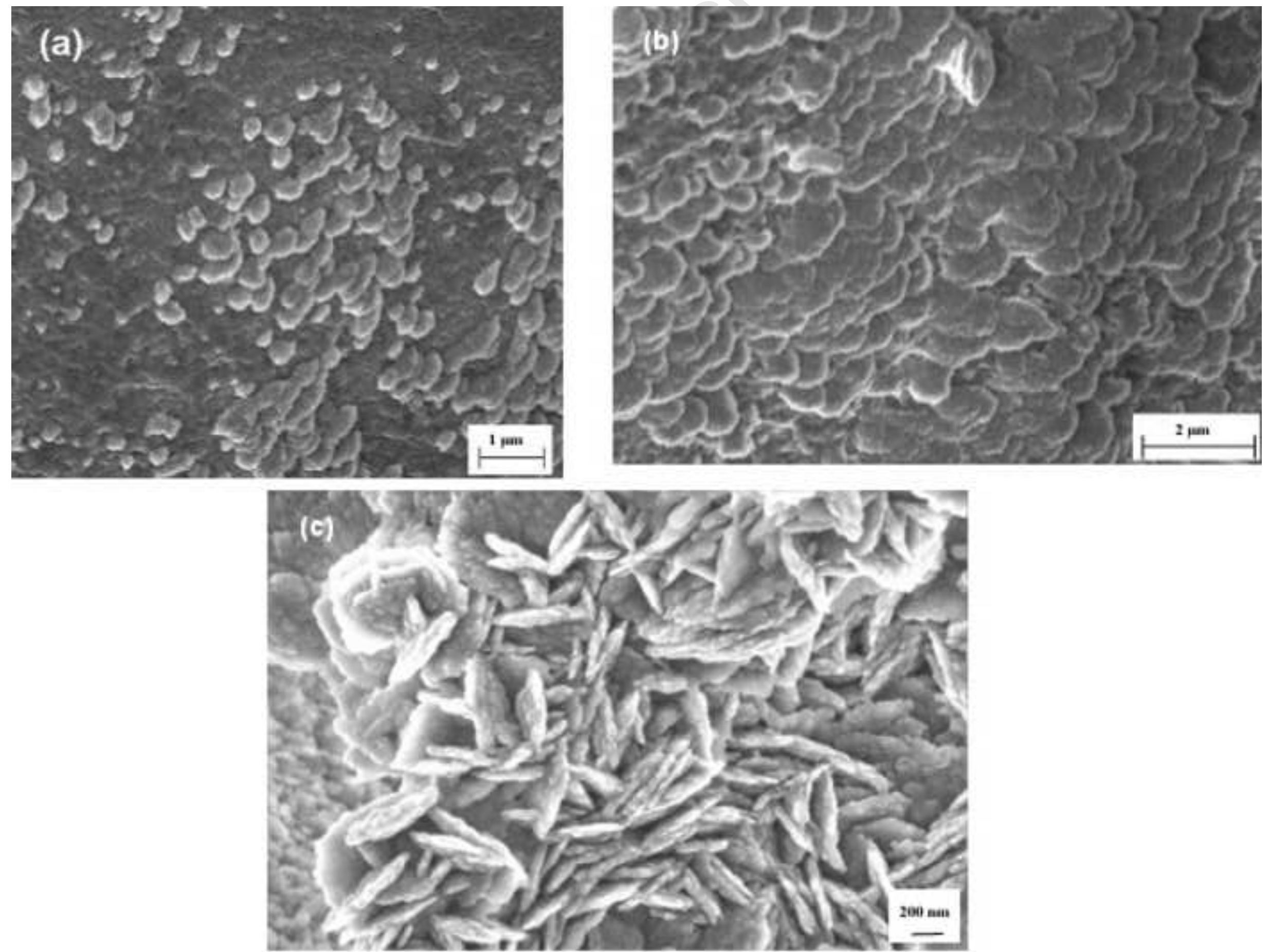


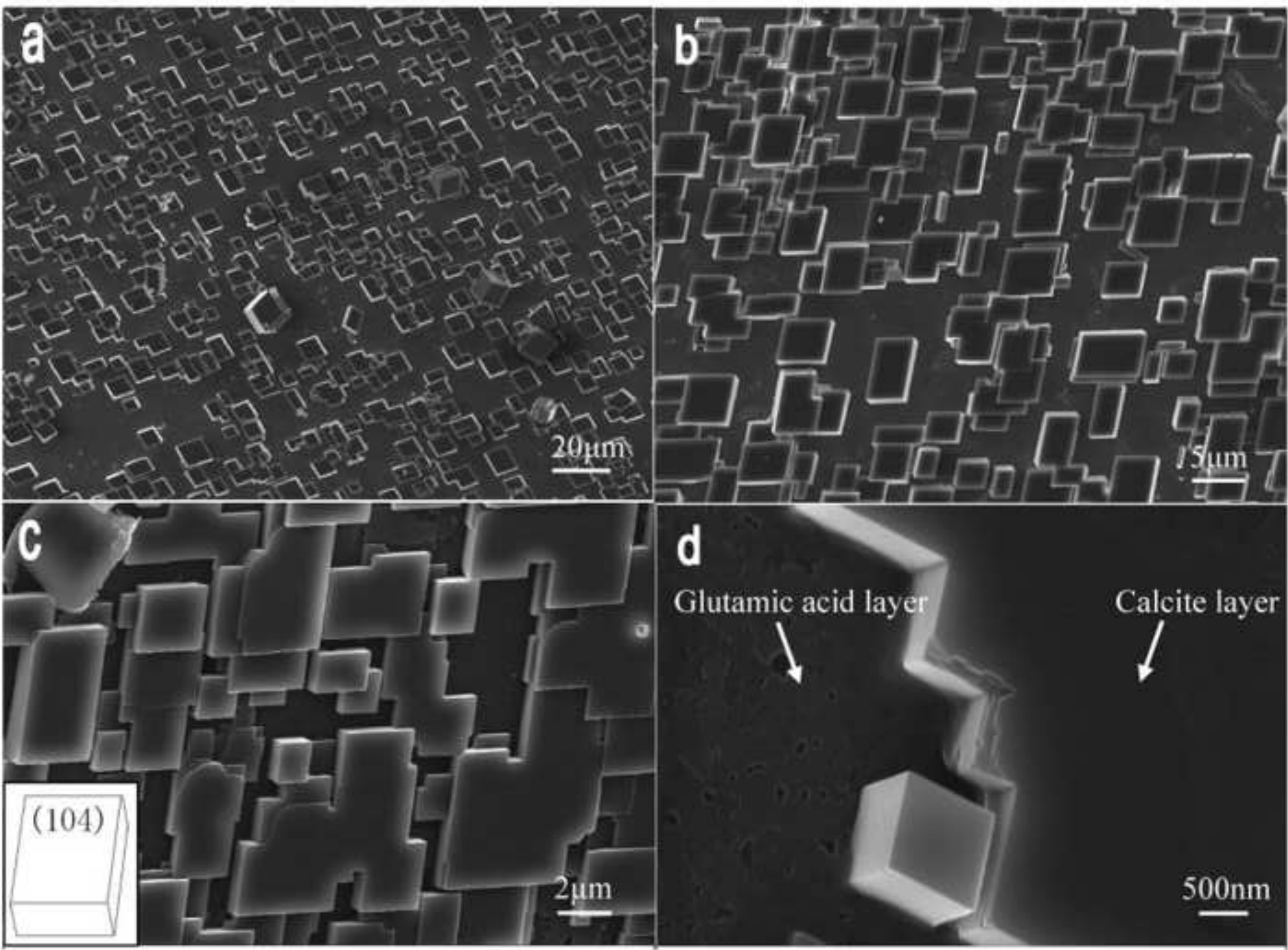




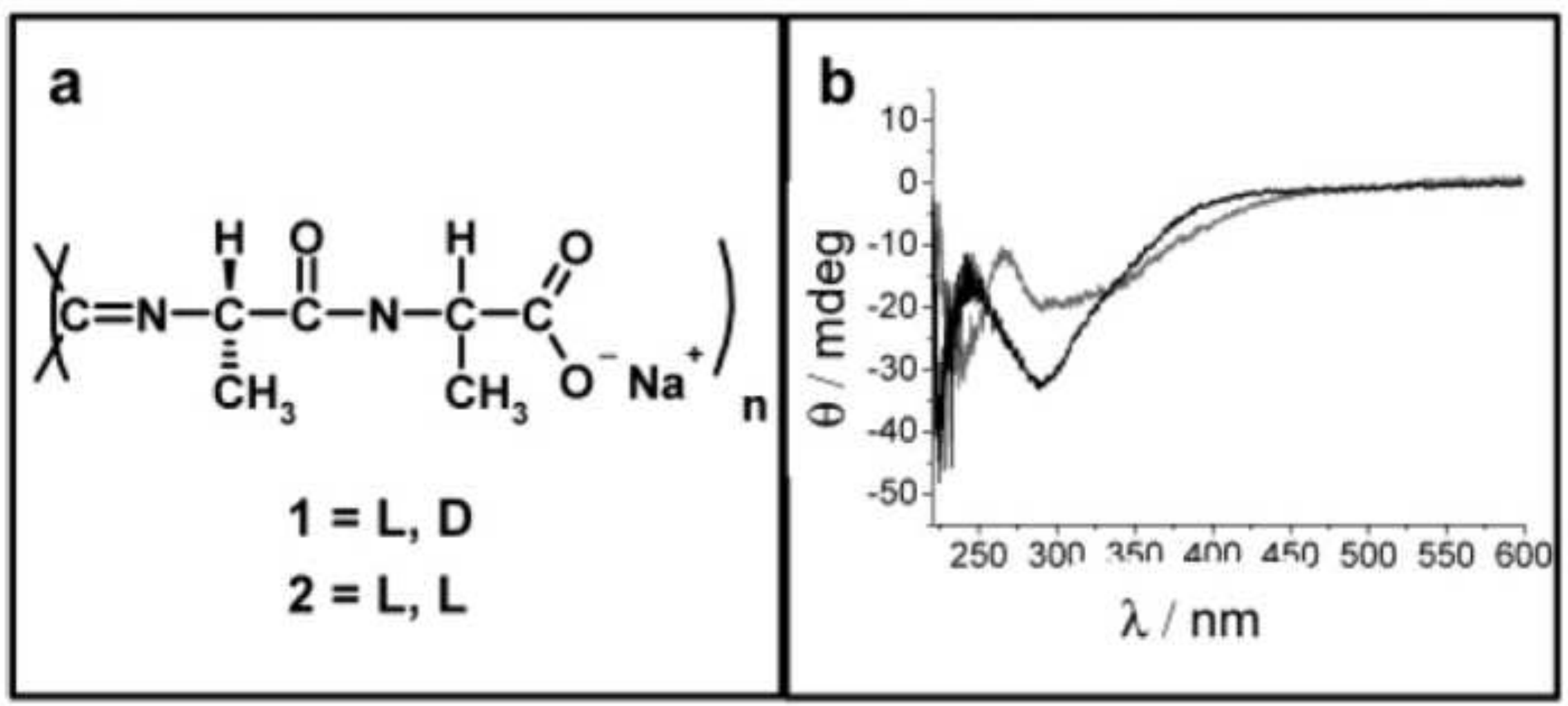




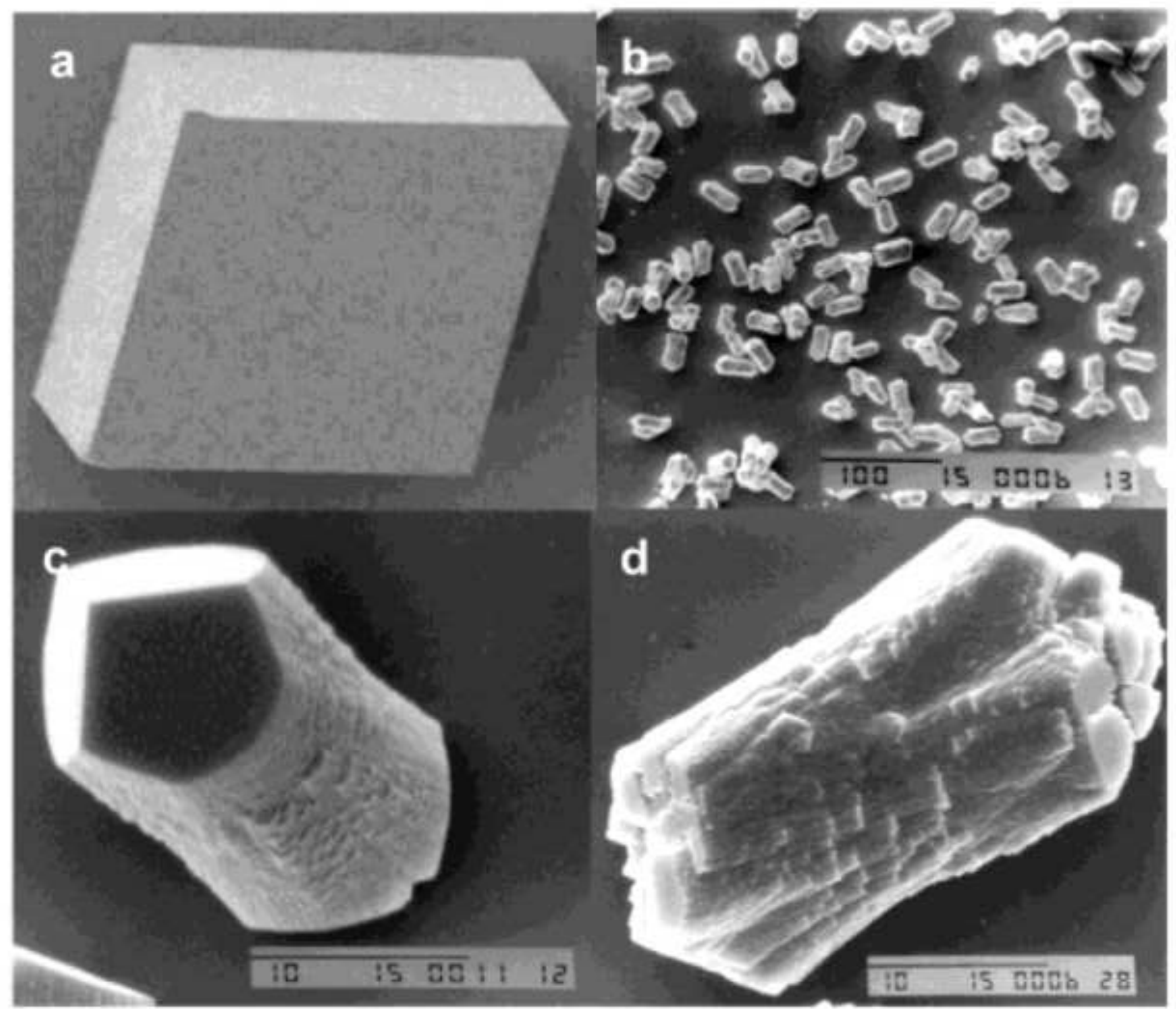


Table 1. Different calcium carbonate mineralization results with different additives

and templates

\begin{tabular}{|c|c|c|}
\hline & Influences & References \\
\hline \multicolumn{3}{|l|}{ Additives } \\
\hline \multirow[t]{4}{*}{ Soluble matrices } & $\begin{array}{l}\mathrm{SM} \text { could mediate the same } \mathrm{CaCO}_{3} \text { crystal } \\
\text { polymorphs with the biominerals of which } \\
\text { SM were extracted. }\end{array}$ & $\begin{array}{l}\text { Feng et al., 2000; Belcher et } \\
\text { al., 1996) }\end{array}$ \\
\hline & $\begin{array}{l}\text { IM proteins mainly act as structure frames, } \\
\text { providing nucleation sites for calcium } \\
\text { carbonate crystals while SM proteins control } \\
\text { the polymorphs. }\end{array}$ & $\begin{array}{l}\text { Feng et al., 2000; Belcher et } \\
\text { al., 1996; Falini, 1996; Samata } \\
\text { et al., 1999; Kono et al., } 2000\end{array}$ \\
\hline & $\begin{array}{l}\text { Besides SM, IM could also control calcium } \\
\text { carbonate crystal polymorphs. }\end{array}$ & Falini, 1996 \\
\hline & $\begin{array}{l}\text { New protein matrices extraction method } \\
\text { divided soluble protein matrices into WSM } \\
\text { and ASM. }\end{array}$ & Pereira-Mouries et al., 2002 \\
\hline \multirow[t]{2}{*}{ Amino acids } & $\begin{array}{l}\text { Glycine could mediate vaterites, probably by } \\
\text { changing the activation energy of } \mathrm{CaCO}_{3} \\
\text { nucleation. }\end{array}$ & Hou and Feng, 2006 \\
\hline & $\begin{array}{l}\text { Glutamic acid and aspartic acid are both } \\
\text { acidic amino acids, could induce vaterite } \\
\text { growth in solution, they could also influence } \\
\text { crystal morphology. }\end{array}$ & $\begin{array}{l}\text { Tong et al., 2004; Manoli and } \\
\text { Dalas, 2001; Hou and Feng, } \\
2006\end{array}$ \\
\hline \multirow[t]{3}{*}{$\begin{array}{l}\text { Magnesium ions } \\
\text { and collagen }\end{array}$} & $\begin{array}{l}\mathrm{Mg}^{2+} \text { can replace } \mathrm{Ca}^{2+} \text { in calcite, in } \\
\text { conditions of high } \mathrm{Mg} / \mathrm{Ca} \text { ratio, calcite } \\
\text { nucleation would be inhibited and aragonite } \\
\text { nucleation would be favored. } \mathrm{Mg}^{2+} \text { could } \\
\text { promote amorphous calcium carbonate } \\
\text { (ACC) formation. }\end{array}$ & $\begin{array}{l}\text { Mann, 2001; Raz et al., 2003; } \\
\text { Loste et al., } 2003\end{array}$ \\
\hline & $\begin{array}{l}\text { Collagen does not change the polymorph of } \\
\text { calcium carbonates, calcite growth is more } \\
\text { and more inhibited as collagen concentration } \\
\text { increasing, and the morphology changes } \\
\text { with the collagen concentration. }\end{array}$ & Shen et al., 2002 \\
\hline & $\begin{array}{l}\text { Collagen had a promotional effect on } \\
\text { magnesium ions in controlling the } \\
\text { polymorph of } \mathrm{CaCO} 3 \text { crystals. }\end{array}$ & Jiao et al., 2006 \\
\hline $\begin{array}{l}\text { Non-biological } \\
\text { macromolecules }\end{array}$ & $\begin{array}{l}\text { Using different additives, such as } \\
\text { poly-aspartic acid; poly-aspartic acid and } \\
\text { poly-glutamic acid gels; chitin, poly(acrylic } \\
\text { acid) and } \mathrm{Mg}^{2+} \text {; dextran, scientists } \\
\text { successfully produced calcite crystals with }\end{array}$ & $\begin{array}{l}\text { Gower and Tirrell, 1998; } \\
\text { Falini, 2000; Falini et al., } \\
\text { 2000; Kato, 2000; Hardikar } \\
\text { and Matijevic, 2001 }\end{array}$ \\
\hline
\end{tabular}




\begin{tabular}{|c|c|c|}
\hline & $\begin{array}{l}\text { spiral holes on the surface; calcite, aragonite } \\
\text { and vaterite crystals with certain } \\
\text { orientations; aragonite double-layered } \\
\text { composite film } \text { et al. }\end{array}$ & \\
\hline & $\begin{array}{l}\text { DHBCs were also used: PEO-b-PAA could } \\
\text { stabilize spherical ACC particles; } \\
\text { PEO-b-PNaSS could affect calcite particle } \\
\text { morphology change. }\end{array}$ & $\begin{array}{l}\text { Guillemet et al., 2006; Kulak } \\
\text { et al., } 2007\end{array}$ \\
\hline \multicolumn{3}{|l|}{ Templates } \\
\hline $\begin{array}{l}\text { Self-assembled } \\
\text { monolayers } \\
\text { (SAMs) }\end{array}$ & $\begin{array}{l}\text { Micropatterned self-assembled monolayers } \\
\text { (SAMs) with special X-terminal exposed } \\
\left(\mathrm{X}=\mathrm{COOH}, \mathrm{SO}_{3} \mathrm{H}, \mathrm{OH}\right) \text { was used to } \\
\text { synthesize patterned calcite films of which } \\
\text { the nucleation, size and orientation of the } \\
\text { crystals could be controlled. }\end{array}$ & Aizenberg, 2000 \\
\hline \multirow[b]{2}{*}{$\begin{array}{l}\text { Glass, single } \\
\text { crystal silicon } \\
\text { and modified } \\
\text { single crystal } \\
\text { silicon }\end{array}$} & Glass surface may induce aragonite crystals. & Hou and Feng, 2005 \\
\hline & $\begin{array}{l}-\mathrm{OH},-\mathrm{NH}_{2} \text { and }-\mathrm{COOH} \text { grafted single } \\
\text { crystal silicon were used to study the effects } \\
\text { of different radical: calcite aggregates were } \\
\text { formed on -OH surface, surface with }-\mathrm{NH}_{2} \\
\text { had no influence on crystal polymorph; a } \\
\text { small amount of vaterites were formed on } \\
\text {-COOH surface. WSM and ASM from } \\
\text { otoliths adsorbed silicon substrates were also } \\
\text { used: those of lapillus could induce } \\
\text { aragonites, while those from asteriscus had } \\
\text { little crystal polymorph effect. }\end{array}$ & Li, 2008 \\
\hline \multirow[t]{3}{*}{$\begin{array}{l}\text { Natural } \\
\text { biomineral }\end{array}$} & $\begin{array}{l}\text { Fresh cross-section of nacre surface of } \\
\text { freshwater lustrous pearls (aragonite) as } \\
\text { templates was used: the formation process } \\
\text { was developed from an ACC layer, } \\
\text { iso-oriented nano-stacks to hexagonal } \\
\text { aragonite tablets. }\end{array}$ & Qiao, 2008 \\
\hline & $\begin{array}{l}\text { The fresh cross-section of lapillus and } \\
\text { asteriscus were used: perfect aragonite } \\
\text { formed on the surface of lapillus (aragonite), } \\
\text { and perfect vaterite crystals formed on the } \\
\text { surface of asteriscus (vaterite). }\end{array}$ & $\mathrm{Li}, 2008$ \\
\hline & $\begin{array}{l}\text { Acid insoluble matrix (AIM) of aragonite } \\
\text { and vaterite pearls were used and perfect } \\
\text { calcite crystals were formed on both two } \\
\text { templates, which showed no influences on } \\
\text { crystal polymorphs or morphologies. }\end{array}$ & Qiao, 2008 \\
\hline Other templates & Amino acid modified calcite substrate was & Qiao et al., 2008 \\
\hline
\end{tabular}




\begin{tabular}{|l|l|l|}
\hline & $\begin{array}{l}\text { used and calcite crystals with uniform size, } \\
\text { distribution and orientation were deposited. }\end{array}$ & \\
\cline { 2 - 3 } & $\begin{array}{l}\text { A shape-persistent polymeric template } \\
\text { composed of alanyl-alaninederived } \\
\text { poly(isocyanide)s was used and calcite } \\
\text { crystals with apple core-type morphology } \\
\text { were formed. }\end{array}$ & Donners et al., 2002 \\
\hline
\end{tabular}

